\title{
Temperature-dependent digestion handling time in juvenile cod and possible consequences for prey choice
}

\author{
Ian Knutsen, Anne Gro Vea Salvanes* \\ Department of Fisheries and Marine Biology, Bergen High Technology Centre, University of Bergen, PO Box 7800 , \\ N-5020 Bergen, Norway
}

\begin{abstract}
The paper combines experimental work with modelling. The aim was to estimate the temperature-dependent digestion handling time, which is defined as the time taken to digest the whole prey or the whole stomach contents, and to examine potential consequences of prey digestibility on prey choice. A surface-dependent digestion model that reflects the geometric shape of a piscivore prey was applied to experimental data representing the weight of prey remaining undigested at various points in time from the time at which the prey was first ingested. The fish used were juvenile cod fed different meal sizes of two-spotted goby Gobiusculus flavescens Fabricius at 4 temperatures. It is assumed that prey digestion is a surface process in which digestive enzymes attack progressively deeper into a prey of known size and shape so that the average digestion rate would be proportional to prey radius. This process is characterized by the digestion velocity $d_{s}\left(\mathrm{~cm} \mathrm{~h}^{-1}\right)$ and the digestion handling time. $d_{\mathrm{s}}$ was estimated for various meal sizes and temperatures. Next, these estimates were used to obtain a standardized temperature-dependent function: $d_{s}=d_{\mathrm{s} 0}\left[\mathrm{e}^{\mid(\mathrm{tn} 341 / 10) T}\right]$, of which the standardized digestion velocity estimate at $0^{\circ} \mathrm{C}, d_{\mathrm{s}}=0.0026 \mathrm{~cm} \mathrm{~h}^{-1}$ The $d_{\mathrm{s}}$ relation expresses the digestion velocity over a 10 -fold meal size increase for a temperature range within natural seasonal variation for the cod. The digestion velocity $d_{s}$ was constant for a 10 -fold difference in meal size within the temperature range. However, the digestion handling time increased with increasing meal size, but decreased with increasing temperature. It was demonstrated that predictions from a modified prey choice model which incorporates the effect of digestion differ from predictions from classical models which do not account for prey digestion.
\end{abstract}

KEY WORDS: Juvenile cod · Prey · Digestion - Temperature - Feeding behaviour

\section{INTRODUCTION}

Behavioural models have been developed with the aim of understanding the mechanisms that control food intake and feeding behaviour in fish. The models describe, in mathematical terms, the criteria a forager is assumed to act upon. Classic foraging theory (Emlen 1966, MacArthur \& Pianka 1966, Fretwell \& Lucas 1970, Charnov 1976) has identified important elements that a forager should respond to in order to feed most efficiently. However, early foraging models have been criticized for not considering the continuously changing state of both the environment and the animal itself

•E-mail: anne.salvanes@ifm.uib.no (e.g. Pyke 1984, Hart \& Ison 1991). This criticism has been met by the introduction of dynamic modelling (Mangel \& Clark 1986, 1988) which forms the basis of behavioural models which consider the dynamic change in state of the animals.

The nutritional state of an animal can be viewed with respect to its energy resources over its life-history (Bull et al. 1996), or on a day-to-day basis for the more immediate concerns such as prey choice and stomach filling (Hart \& Ison 1991, Salvanes \& Hart 1998). For a predator becoming satiated, motivation to resume feeding will be related to the size of its previous meals (Grove et al. 1978, 1985). Satiation will also affect the time of handling prey (Street et al. 1984). Handling time has traditionally been restricted to the time 
between the capture of the prey and the ingestion (Stephens \& Krebs 1986). A model that aims to trace the dynamics of predation and feeding behaviour should consider the full aspects of feeding and specify both length in time required in pursuit of the prey and restrictions associated with digestion in the handling time. However, for effective application of such a model, it is required that good predictions of parameters that reflect the digestion process are available Such parameters are established through digestion experiments and depend upon digestion models that are biologically meaningful.

Digestion studies have been performed on a large number of species and prey (for reviews see Kapoor et al. 1975, Fänge \& Grove 1979, Jobling 1988, Rodrigues 1994) and many have used cod Gadus morhua L. as a predator (Karpevich \& Bokova 1937, Tarverdieva 1962, Tyler 1970, 1977, Daan 1973, Jones 1974, Bagge 1977, Macdonald et al. 1982, dos Santos \& Jobling 1988, 1991a, 1991b, 1992, Bromley 1991, Singh-Renton \& Bromley 1996), most of which have dealt with adult cod digesting major prey organisms which are easy to catch in sufficient quantities (Knutsen 1998). Ontogenetic differences in prey digestion may also exist and predator species and type of food items are also of importance (Kapoor et al. 1975, Fänge \& Grove 1979). Although a number of prey may have similar digestibility (Persson 1979), thus making generalisations possible for use in ecosystem models, other important factors that have a large influence on digestion such as temperature and meal sizes need to be quantified (Windell 1978). In Salvanes et al. (1995) parameters that express prey digestion were estimated for adult cod at short temperature intervals from 1.2 to $6^{\circ} \mathrm{C}$, but also for $9.5^{\circ} \mathrm{C}$. In the present paper we focus on juvenile cod and the temperature range of 6 to $12^{\circ} \mathrm{C}$.

Digestion models describe how a prey or a prey bolus decreases in size with time after being ingested. The lack of information on all factors that influence digestion has led to a common practice of fitting the experimental data to empirical models which a priori seem to fit best to the data by means of regression analysis (Elashoff et al. 1982). Empirical models used are linear (e.g. Daan 1973), exponential (e.g. Tyle. 1970), square root (e.g. Hopkins 1966), or logistic (e.g. Macdonald et al. 1982) equations. Estimated parameters from such regressions have often limited biological meaning (e.g. Tseitlin 1980), and different parameter estimates would be required e.g. for each set of temperature, predator species, prey species and meal sizes. An alternative model to the empirical models is the surface-dependent digestion model outlined, and applied to data on adult cod, by Salvanes et al. (1995). It is based on the assumption that digestion is a surface process, in which digestive enzymes attack the surface and penetrate progressively deeper into the prey with an average rate $d_{s}$ so the digestive process can be expressed as a velocity, i.e. the thickness of a prey layer that is digested per time unit. This implies that digestion would be dependent on geometry of the stomach contents.

In the present study, the surface-dependent digestion model of Salvanes et al. (1995) is applied in an analysis of digestion handling time for juvenile coastal cod, when different meal sizes of two-spotted goby Gobiusculus flavescens Fabricius are given to groups of cod kept at various experimental temperatures. The two-spotted goby is very abundant in the coastal and fjord areas of western Norway and constitutes the main prey for young coastal cod inhabiting the sublittoral zone (Godø et al. 1989, Svåsand \& Kristiansen 1990, Fosså 1991, Hop et al. 1992, 1994, Salvanes \& Noreide 1993). The digestion velocity parameter $d_{s}$ is first estimated with values of uncertainty for every meal size and for each experimental temperature. Next, these estimates are used to obtain a general temperature- and meal-size-dependent function which expresses how the digestion velocity and digestion handling time of prey changes with changing environmental temperature and with the amount of prey consumed. We also modify a classical optimal diet breadth model to take into account the effect of digestion and we illustrate the possible implications of this on predicted optimal prey choice. It is shown by simulation that the incorporation of the digestion can alter the predicted optimal diet as compared with predictions from a classical approach.

\section{MATERIAL AND METHODS}

About 200 healthy juvenile cod were kept from mid July 1995 in 2 storage tanks $\left(500\right.$ l) at $10^{\circ} \mathrm{C}$ under natural photoperiod. Formulated feed was provided twice a week. Fish were measured (Table 1) and transferred to the experimental tanks and to a piscivorous diet in early January 1996. Acclimation period to the fish diet lasted 1 wk. Experimental prey, two-spotted goby, were collected using a beach seine at 0 to $5 \mathrm{~m}$ depth in autumn and spring. Because it was impossible to have a continuous supply of fresh prey during the whole experimental period due to strong seasonal variation in prey abundance, the prey were frozen and stored at $-18^{\circ} \mathrm{C}$ before use. This could cause over-estimation of the digestion rate of frozen prey in comparison to fresh (Bromley 1994). Similar sized whole prey were selected for the 4 Experimental Series. The series consisted of groups of 10 or $20 \mathrm{cod}$ in $500 \mathrm{l}$ tanks. These are referred to according to the temperature used (Table 1). Salinity averaged $33.3 \%$ ( $\mathrm{SE}=0.05, \mathrm{n}=34)$. Sufficient 
water flow secured oxygen levels high above the maximum metabolic requirements of cod (Schurmann \& Steffensen 1997). Light was adjusted to a $12 \mathrm{~h}$ day : $12 \mathrm{~h}$ night regime. The number of prey given per tank per trial was equivalent to an average of 6 gobies (average weight $0.60 \pm 0.02 \mathrm{~g}$ ) which represented $4.5 \%$ of body weight per individual. According to dos Santos \& Jobling (1992) this would represent half of the expected maximum stomach capacity. Individual fish ate a variable number of prey, generating data for a range of meal sizes.

Experimental series. Feeding: Regular feeding was terminated at least $3 \mathrm{~d}$ before each trial took place. It was assumed that $3 \mathrm{~d}$ would be a sufficient amount of time for the fish to empty their stomachs of any prey remaining at the temperatures used (Windell 1966, Brett \& Higgs 1970, Elliott 1972). The gobies were gently dispersed over the entire water surface in each tank to give individual cod equal opportunities to take prey. After $1 \mathrm{~h}$ the gobies not eaten were collected, counted and weighed. After a predetermined time for meal digestion had elapsed, the remnants of the meal were retrieved by the gastric lavage technique (Bromley 1988, 1991, dos Santos \& Jobling 1991a). To ensure that this was an effective way to empty the fish stomachs, we used an extra group of cod which were emptied, killed and then dissected. All stomachs were found empty. The solid remains of the digested gobies were collected by forceps and placed on a moist paper towel to remove excess liquid. The gobies were counted and put in a pre-weighed disposable weighing vessel. It took about $1 \mathrm{~h}$ to perform gastric lavage on $10 \mathrm{cod}$. The vessels containing the remnants of the stomach contents were weighed to $\pm 0.0001 \mathrm{~g}$. Because the experimental fish were healthy it is likely that the individual variation in the degree of digestion of the stomach contents at time $t$ reflects the combined effect of the small variation in goby size and the individual variation in the digestion of prey. The gastric lavage technique is unlikely to affect future digestion velocity or induce any lasting changes to digestion physiology (Seaburg \& Moyle 1964, Bromley 1988, 1991, Hartleb $\&$ Moring 1995). The cod in the present study rapidly recovered appetite and resumed feeding behaviour within $2 \mathrm{~h}$ after being lavaged. It might be argued that repeated handling of the fish could lead to cumulative stress, but this was found not to be the case by dos Santos \& Jobling (1988). All cod in each tank were sampled after a pre-set time interval. The time from feeding to gastric lavage was varied from 2 to $26 \mathrm{~h}$, with intervals of approximately $2 \mathrm{~h}$. After $30 \mathrm{~h}$ of digestion, at $12^{\circ} \mathrm{C}$, the prey items were reduced to such a condition that recognition of the number of prey was not easily made (Daan 1973). Only 1 trial could be made per experimental tank at any one time.

Theory of gastric evacuation. Definitions of terms used: Digestive chyme is depleted from the stomach during the same time as the digestion process of the prey (Tyler 1970) and therefore terms are often interchanged. Table 2 provides a definition of the terms as used in the present study.

Conventional models: The simplest mathematical model that aims to describe the pattern of gastric evacuation is the linear $W_{t}=W_{0}-d_{1} \cdot t_{\text {t }}$ in which $W_{t}$ is the weight of prey remaining at time $t$, assuming a constant emptying rate $\left(d_{t}\right)$ independent of meal size consumed $\left(W_{0}\right)$ and time after feeding $(t)$. It is commonly used where ordinary least squares (OLS) regression analysis gives a good fit to experimental data (Daan 1973, Bagge 1977), but has been criticised for lacking a sound biological basis (Olson \& Mullen 1986).

The exponential digestion model $\left(W_{t}=W_{0} \cdot \mathrm{e}^{-g \cdot t}\right)$, in which $g$ refers to the specific gastric evacuation rate $\left(\mathrm{g} \mathrm{g}^{-1} \mathrm{~h}^{-1}\right)$, assumes digestion to proceed faster in the early phase of digestion and then level off at the later stages. This corresponds with common observations of the retention of less digestible solids. However, both bones and chitinious exoskeletons are eventually broken down and evacuated, contradicting the non-intercepting asymptotic approximation to zero of the exponential model (when $t \rightarrow \infty$ ). The predicted weight of the prey $\left(W_{t}\right)$ when $t=0$ should also be identical to the initial weight of the prey $\left(W_{0}\right)$, which is not always the case. By raising the equation to a power of $2 / 3$ (Tyler 1970, Jobling 1981b), the exponential model aims to cover the relationship between surface area and volume during digestion $\left(\mathrm{m}^{2} / \mathrm{m}^{3}\right)$. The exponential model still gives a good description of the diges-

Table 1. Sizes (mean $\pm \mathrm{SE}$ ) of experimental fish at the start of each experimental series and numbers of tanks, trials cod per tank and prey per trial. $n_{s}$ : number of cod the size measurements are based $u_{p o n} n_{1}$ : number of temperature measurements

\begin{tabular}{|lccccccccc|}
\hline $\begin{array}{l}\text { Experimental } \\
\text { series }\end{array}$ & $\begin{array}{c}\text { Date } \\
(1996)\end{array}$ & $\begin{array}{c}\text { Length } \\
(\mathrm{cm})\end{array}$ & $\begin{array}{c}\text { Weight } \\
(\mathrm{g})\end{array}$ & $\mathrm{n}_{\mathrm{s}}$ & $\begin{array}{c}\text { Temperature } \\
\left({ }^{\circ} \mathrm{C}\right)\end{array}$ & $\mathrm{n}_{\mathrm{t}}$ & $\begin{array}{c}\text { No. of } \\
\text { tanks }\end{array}$ & $\begin{array}{c}\text { No. of cod } \\
\text { per tank }\end{array}$ & $\begin{array}{c}\text { No. of prey } \\
\text { per trial }\end{array}$ \\
\hline 1 & Jan 18 & $20.14 \pm 0.35$ & $74.29 \pm 3.04$ & 40 & $5.9 \pm 0.02$ & 18 & 3 & 20,20 and 10 & 120,120 and 60 \\
2 & Jan 18 & $20.43 \pm 0.33$ & $81.22 \pm 4.28$ & 40 & $8.1 \pm 0.07$ & 18 & 3 & 20,10 and 10 & 120,60 and 60 \\
3 & May 13 & $23.25 \pm 0.33$ & $116.51 \pm 5.88$ & 39 & $10.1 \pm 0.03$ & 11 & 2 & 20 and 20 & 120 and 120 \\
4 & May 13 & $24.98 \pm 0.39$ & $145.60 \pm 6.67$ & 39 & $12.4 \pm 0.10$ & 11 & 2 & 20 and 20 & 120 and 120 \\
\hline
\end{tabular}


Table 2. Definitions of common terms relating to the process of food consumption, as used in this study

\begin{tabular}{|c|c|}
\hline Term & Definition \\
\hline Digestion & $\begin{array}{l}\text { The sum of all mechanical and chemical processes that food goes through from ingestion } \\
\text { until it is in the intestine ready to be absorbed }\end{array}$ \\
\hline Digestion velocity & $\begin{array}{l}\text { The speed at which stomach contents are disintegrated weight }(\mathrm{g}) \text {, proportion }(\%) \text { or } \\
\text { metric measure }(\mathrm{cm}) \text { per time unit }\end{array}$ \\
\hline Digestion handling time & $\begin{array}{l}\text { The time interval between capture of and passage of food from the stomach to the } \\
\text { intestine (see } t_{\max } \text { in Table } 4 \text { ) }\end{array}$ \\
\hline Gastric evacuation & $\begin{array}{l}\text { Emptying of breakdown products from the stomach, through the pyloric sphincter, into } \\
\text { the small intestine }\end{array}$ \\
\hline Gastric evacuation velocity & $\begin{array}{l}\text { The speed at which gastric evacuation takes place; weight }(\mathrm{g}) \text { or proportion }(\%) \text { per } \\
\text { time unit }\end{array}$ \\
\hline Gastric motility & The muscular contractions of the stomach wall \\
\hline
\end{tabular}

Table 3. The value of the exponent $d$ of the derivative of the digestion model predicts the categorisation of the model (after Bromley 1994)

\begin{tabular}{|lll|}
\hline Value & \multicolumn{1}{c}{ Resulting model } & Gastric evacuation pattern \\
\hline$d<0$ & Convex & Initially slow, then increasing \\
$d=0$ & Linear & Constant rate \\
$0<d \leq 1$ & Concave power curve & Initially fast, then decreasing \\
$d=1 / 2$ & Square root & Initially fast, then decreasing \\
$d=2 / 3$ & Surface/volume & Initially fast, then decreasing \\
$d=1$ & Exponential & Gastric evacuation is a function of \\
& & $\begin{array}{l}\text { level of fullness and will therefore } \\
\text { never empty completely }\end{array}$ \\
$d>1$ & Pronounced convex & Quick at large meals, slow at small \\
\hline
\end{tabular}

the stomach, thereby making the instantaneous rate of depletion $\left(d_{\mathrm{sq}}\right)$ dependent upon the amount of food in the stomach. The model has shown to describe digestion in plaice Pleuronectes platessa L. well (Jobling \& Davies 1979), even though this may be a result of force feeding (Persson 1986).

Derivation of any of these models results in the general equation

$$
\frac{\mathrm{d} W}{\mathrm{~d} t}=-R \cdot W^{d}
$$

where $R$ and $d$ are constants (Bromley 1994). Table 3 explains how the derivative of gastric evacuation models are interpreted. From this it is shown that the exponential, square root

tion process and is commonly used for a variety of species and prey, e.g. brown trout Salmo trutta L. (Elliott 1972), bluegill sunfish Lepomis macrochirus Rafinesque (El-Shamy 1976) and also cod (Tyler 1970).

The power exponential model $\left[W_{t}=W_{0} \cdot 2^{-(t H)^{s}}\right]$ (Elashoff et al. 1982) is similar to the exponential model. It has a 'half life' parameter of the decaying prey $(H)$ and the advantage of a shape coefficient, $s$. The latter makes it extremely versatile and convertible to a linear, sigmodial or exponential evacuation pattern. The model enables good description of experimental data, but it may be difficult to fit or to decide in which form to fit it (Bromley 1994). The biological meaning of the parameters is not obvious.

The square root model (Hopkins 1966) has a more biological basis. Gastric motility is induced by stretch receptors in the stomach wall and the frequency of peristalsis is related to the size of the meal. The square root digestion model $\left[W_{i}=\left(\sqrt{W_{0}}-d_{s q} \cdot t\right)^{2}\right]$ is based on the proportional relationship between the peristaltic contractions and the stretching of
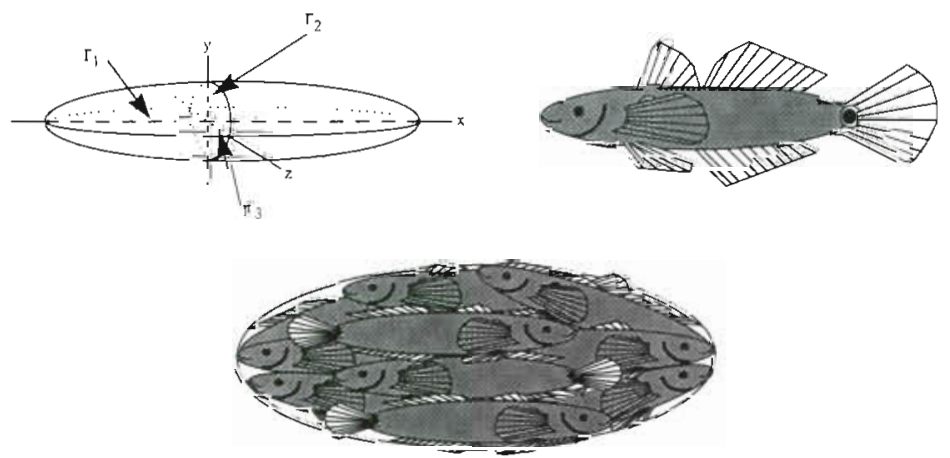

Fig. 1. Illustration of the approximate geometric shape of a piscivorous prey item. $r_{1}, r_{2}, r_{3}$ : the 3 radii of the ellipsoid. $r_{1}$ refers to $L_{0} / 2$ and $r_{2}=r_{3}$ refers to $r_{0}$ (cf. Table 4) 
Table 4. Parameters and variables used in the surface-dependent digestion model (modified after Salvanes et al. 1995)

\begin{tabular}{|c|c|c|}
\hline Symbol & Description & Unit \\
\hline a & Temperature coefficient per ${ }^{\circ} \mathrm{C}$ for enzymatic processes & ${ }^{\circ} \mathrm{C}^{-1}$ \\
\hline$d_{s}$ & Digestion velocity & $\mathrm{cm} \mathrm{h}^{-1}$ \\
\hline$d_{\mathrm{s} 0}$ & Digestion velocity at $0^{\circ} \mathrm{C}$ & $\mathrm{cm} \mathrm{h}^{-1}$ \\
\hline$L_{0}$ & Total length of a fresh prey & $\mathrm{cm}$ \\
\hline$\pi$ & Ratio of the circumference of any circle to its diameter & - \\
\hline$Q_{10}$ & Temperature rate constant per $10^{\circ} \mathrm{C}$ for enzymatic processes & $10^{\circ} \mathrm{C}^{-1}$ \\
\hline$r$ & Prey radius at any time after a meal & $\mathrm{cm}$ \\
\hline$r_{0}$ & Radius of a fresh prey/prey bolus & $\mathrm{cm}$ \\
\hline$\rho$ & Density of prey mass & $\mathrm{g} \mathrm{cm}^{-3}$ \\
\hline$\hat{\sigma}_{\varepsilon}$ & Standard error of the equation & g \\
\hline T & Temperature & ${ }^{\circ} \mathrm{C}$ \\
\hline$t$ & Time after a meal was ingested & h \\
\hline$t_{\mathrm{D}}$ & Time delay before digestion starts & $\mathrm{h}$ \\
\hline$t_{\max }$ & Time taken to digest the whole prey or the whole stomach contents & $\mathrm{h}$ \\
\hline$W_{0}$ & Initial prey weight & $\mathrm{g}$ \\
\hline$W_{t}$ & Weight of prey remaining at time $t$ & g \\
\hline$H_{j}$ & Handling time from encounter until ingestion of prey $j$ & $\mathrm{~h}$ \\
\hline$H_{d}$ & Handling time from ingestion and until fish resumes feeding & h \\
\hline$F_{1}$ & Feeding rate on prey $j$ & $g h^{-1}$ \\
\hline$\lambda_{j}$ & Encounter rate of prey $j$ & no. $h^{-1}$ \\
\hline
\end{tabular}

terns from linear to very curved. The basis for this model is that digestion in fish is essentially a surface process. The results of Flowerdew \& Grove (1979) and Grove et al. (1985) on turbot Schopthalmus maximus L. also support the idea that digestion is a surface process. Enzymes attack the surface of the prey and work their way progressively deeper into the flesh. Digestion can thus be described as a function of the geometrical shape of the prey or of a bolus in the stomach contents of fish. A piscivorous prey item approximates a shape similar to an ellipsoid (Fig. 1).

We now assume that the digestive enzymes attack the surface and digest progressively deeper into the center of the stomach contents at a digestion speed of $d_{\mathrm{s}}\left(\mathrm{cm} \mathrm{h}^{-1}\right)$ and that the time $t_{\max }$ needed to digest a homogenous prey item or prey bolus will be proportional to the thickness of the prey $r$ so that $t_{\max }=r_{0} / d_{\mathrm{s}}$. After $t$ hours of digestion time for $0 \leq t \leq t_{\max }$, the weight of the remaining stomach contents may be expressed as (symbols explained in Table 4):

$$
\begin{aligned}
& W_{t}=\frac{3}{4} \cdot \pi \cdot \rho \cdot\left(\frac{L_{0}}{2}-d_{\mathrm{s}} \cdot t\right) \cdot\left(r_{0}-d_{\mathrm{s} 0} \cdot t\right)^{2} \\
& \text { for limits } t \leq L_{0} / 2 d_{\mathrm{s}} \text { and } t \leq r_{0} / d_{\mathrm{s}}
\end{aligned}
$$

$W_{t}$ is the weight of the prey remaining in the stomach and $L_{0}$ and $r_{0}$ are the initial length and radius, respectively, of the fresh prey. Rates of enzymatic processes can be expressed mathematically as an exponential function of temperature (e.g. Elliott 1972). To take into account varying temperature, Salvanes et al. (1995) expressed $d_{s}$ as the exponential function

$$
d_{\mathrm{s}}=d_{\mathrm{s} 0} \mathrm{e}^{\mathrm{aT}}
$$

where $d_{\mathrm{s} 0}$ is the digestion velocity at $0^{\circ} \mathrm{C}, a=$ $\ln \left(Q_{10}\right) / 10^{\circ} \mathrm{C}^{-1}$ and $T$ is temperature in ${ }^{\circ} \mathrm{C}$. $Q_{10}$ is the temperature rate constant which measures the effect of a $10^{\circ} \mathrm{C}$ rise in temperature on the rate of a chemical reaction (cf. Jobling 1994). Substituting Eq. (3) into Eq. (2) gives

$$
\begin{aligned}
& W_{t}=\frac{3}{4} \cdot \pi \cdot \rho \cdot\left(\frac{L_{0}}{2}-d_{\mathrm{s} 0} \cdot \mathrm{e}^{a T} t\right) \cdot\left(r_{0}-d_{\mathrm{s} 0} \cdot \mathrm{e}^{a T} t\right)^{2} \\
& \text { for limits } t \leq L_{0} /\left(2 d_{\mathrm{s} 0} \cdot \mathrm{e}^{a T} \cdot t\right) \text { and } t \leq r_{0} /\left(d_{\mathrm{s} 0} \cdot \mathrm{e}^{a T}\right)
\end{aligned}
$$

The digestion handling time $\left(t_{\max }\right)$ can be found by solving Eq. (4) with respect to $t$ for $W_{t}=0$, and this represent the limits for Eq. (4). The third-degree polynomial has only 2 solutions, $t_{\max 1}$ and $t_{\max 2}$ :

$$
W_{i}=0 \rightarrow t_{\max 1}=\frac{L_{0}}{2 \cdot d_{\mathrm{s} 0} \cdot \mathrm{e}^{a T}} \wedge t_{\max 2}=\frac{r_{0}}{d_{\mathrm{s} 0} \cdot \mathrm{e}^{a T}}
$$

$t_{\max 2}$ will always reach zero before $t_{\max 1}$ as long as $L_{0} / 2$ $>r_{0}$ (i.e. the fish is longer than its breadth) and both directions are digested at the same velocity. Both solutions are mathematically valid, but since a length without a radius has no biological interpretation, only $t_{\max 2}$ is used when calculating the digestion handling time $t_{\max }$

Modified prey choice model. The total maximum feeding rate $F$ for a predator having a varied diet which consists of $p-1$ prey types can be expressed as the sum of the feeding rates for all prey $F$, as shown in Salvanes (1994): 


$$
F_{p-1}=\sum_{j=1}^{i=p^{-1}} F_{j}=\frac{\sum_{i}^{p-1} \lambda_{j} W_{j}}{1+\sum_{1}^{p-1} \lambda_{j} H_{j}}
$$

where $\lambda_{\text {j }}$ refers to encounter rate with prey type $j, W_{j}$ to the weight of prey type $j$ and $H_{j}$ to the handling time from encounter until ingestion.

The basic assumption of conventional foraging models of mutual exclusion of searching and handling time (Emlen 1966, MacArthur \& Pianka 1966, Charnov 1976) might be too strict. Piscivores can simultaneously digest and seek new prey, as shown by the observations that piscivorous fish are commonly found with more than 1 prey species in the stomach (Daan 1973, Diana 1979). If the handling time associated with digestion of prey $H_{d}\left(0<H_{d} \leq\right.$ $\left.t_{\text {max }}\right)$ is included as part of the handling time, a more dynamic relation may be obtained. It is possible that this could alter the priority of prey acceptance predicted by e.g. the optimal diet breadth model and thereby the predictions from the model. As a constraint caused by the different temperature-dependent digestibility of different prey we illustrate this point by incorporating $H_{d}$ for a given temperature and then modify maximum feeding rate $F_{p-1}$ dampened by digestion constraints to

$$
F_{p-1}^{*}=\frac{\sum_{1}^{p-1} \lambda_{j} W_{j}}{1+\sum_{1}^{p-1} \lambda_{j}\left(H_{j}+H_{d}\right)}
$$

According to optimal prey choice theories a predator can choose among encountered prey and rank prey according to benefit-cost criteria such as energy content per handling time (Shoener 1987) which may be proportional to prey size per handling time (Salvanes 1994). This indicates that some prey will always be consumed if encountered whereas others might not be eaten at all. If a predator should expand its diet, it is likely that this represents a pay-off such as an increased total feeding rate after diet expansion, so that $F_{p}^{*}>F_{p-1}^{*}$ and

$$
\begin{aligned}
\frac{\sum_{1}^{p} \lambda_{j} W_{j}}{1+\sum_{i}^{p} \lambda_{j}\left(H_{j}+H_{d j}\right)} & =\frac{\lambda_{p} W_{p}+\sum_{1}^{p-1} \lambda_{j} W_{j}}{1+\lambda_{p}\left(H_{p}+H_{d p}\right)+\sum_{1}^{p-3} \lambda_{j}\left(H_{j}+H_{d j}\right)} \\
& \frac{\sum_{1}^{p} \lambda_{j} W_{j}}{1+\sum_{1}^{p} \lambda_{j}\left(H_{j}+H_{d j}\right)}
\end{aligned}
$$

Reorganization of Eq. (8) by multiplying the inequality with the denominators and also by eliminating terms which are common to the right- and left-hand sides gives

$$
W_{p}+W_{p} \sum_{j=1}^{p-1}\left(H_{j}+H_{d_{j}}\right) \lambda_{j}>\lambda_{p} \sum_{j=1}^{p-1} \lambda_{j} W_{j}
$$

Inequality (9) is then multiplied with $1 /\left(H_{p}+H_{d p}\right)$ and rearranged to give the expression for minimum pay-off of inclusion of an extra prey, $p$, in the diet:

$$
\frac{W_{p}}{H_{p}+H_{d p}}>\sum_{j=1}^{p-1} \lambda_{j}\left(W_{j}-W_{p} \frac{H_{j}+H_{d j}}{H_{p}+H_{d p}}\right)
$$

The analogous expression for the classical approach when omitting the effect of digestion is (e.g. Charnov 1976)

$$
\frac{W_{p}}{H_{p}}>\sum_{j=1}^{p-1} \lambda_{j}\left(W_{j}-W_{p} \frac{H_{j}}{H_{p}}\right)
$$

Data analysis. Criteria for excluding trials: The total number of gobies given to a tank containing experimental cod, minus the number of prey not taken, should be equal to the number recorded during the gastric lavage of all cod from the tank. To avoid biased results due to collection losses during retrieval of the stomach contents, the data set was excluded from statistical analysis if less than $95 \%$ of the gobies given to a tank were recorded during gastric lavage of the whole group of fish. That is, if more than 3 out of the 60 gobies given to the 10 -cod groups or more than 6 out of the 120 given to the 20 -cod groups were missing in the examined stomach contents of the entire group of fish, the data were excluded from further analysis. Only 3 trials were excluded. Out of 55 trials in our analysis a total of 35 had $100 \%$ prey retrieval.

Parameters used for the digestion model: Initial measurements of the prey $\left(L_{0}\right.$ and $\left.r_{0}\right)$ and observations of the variable $W_{t}$ at various times $t$, provided by the experiments, allow $d_{\mathrm{s}}$ of Eq. (2) to be estimated assuming unit density for goby flesh $\left(1 \mathrm{~g} \mathrm{~cm}^{-3}\right) . d_{s}$ was estimated separately for each experimental temperature, so that a temperature relation between digestion velocity and temperature could be established via the temperature rate $Q_{10}$ parameter. Based on the temperature and $d_{\mathrm{s}}$ relation, Eq. (3) gives $d_{\mathrm{s} 0}$ and thereby an equation that gives the temperature-dependent digestion velocity relationship over all natural temperatures.

By using multiple similar sized prey it is possible to relate the shape of the prey bolus to the shape of the stomach. Examination of cod stomachs showed that the prey bolus increased in length from 1 to 2 prey items, and beyond a length of 2 prey items the bolus mainly increased in diameter. Therefore the parameters used in the surface digestion model were based on the dimensions of a sample of the sorted gobies used in the experiment. The weight of the meal size of a fish $\left(W_{0}\right)$ was set as an arithmetic progression of the mean 
Table 5. Initial weight $\left(W_{0}\right)$ and radius $\left(r_{0}\right)$ of increasing meal sizes of gobies

\begin{tabular}{|ccc|}
\hline No. of prey & $W_{0}(\mathrm{~g})$ & $I_{0}(\mathrm{~cm})$ \\
\hline 1 & 0.5625 & 0.2565 \\
2 & 1.1250 & 0.3628 \\
3 & 1.6875 & 0.4443 \\
4 & 2.2500 & 0.5130 \\
5 & 2.8125 & 0.5736 \\
6 & 3.3750 & 0.6283 \\
7 & 3.9375 & 0.6787 \\
8 & 4.5000 & 0.7255 \\
9 & 5.0625 & 0.7695 \\
10 & 5.6250 & 0.8112 \\
\hline
\end{tabular}

weight of the prey, $0.5625 \mathrm{~g}( \pm 0.0145 \mathrm{~g}, \mathrm{n}=50$, Table 5), for meal sizes consisting of 1 to 10 gobies. $L_{0}$ was set at the mean of total length of the prey $(4.0820$ $\pm 0.0290 \mathrm{~cm}, \mathrm{n}=50$ ) as the stomach length, in the preliminary study, did not increase monotonically with meal size. As an approximation $r_{0}$ was estimated from the weight of the corresponding food bolus $\left(W_{0}\right)$ by solving the equation $W_{0}=\frac{4}{3} \pi \rho \frac{L}{2} r_{0}^{2}$ with respect to $r_{0}$, assuming the density of prey mass $\rho=1 \mathrm{~g} \mathrm{~cm}^{-3}$. Only meal sizes $\leq 10$ gobies were included in the estimation, as more than 10 prey were taken by individual cod only occasionally. If a prey group contained $<5$ observations, it was discarded from the analysis.

Estimations: The maximum likelihood principle was used to estimate the unknown parameters of the model. Given a regression model, the maximum likelihood estimation (MLE) can compute the probability of the specific dependent variable occurring in the sample. The greater the likelihood, the better the fit of the model to the data. The MLE performs well for relatively small sample sizes and is suited to non-linear estimation. The estimator is asymptotically unbiased and consistent, asymptotically efficient and assumed asymptotically normally distributed (Kennedy 1992). The error term of MLE is assumed to be normally distributed, and the validity of this was tested by the Kolmogorov-Smirnov test of normality. The MLE differs from OLS regression by its iterative approach. Initial values for the digestion velocity parameter of Eq. (2) were set to $0.003 \mathrm{~cm} \mathrm{~h}^{-1}$. Other start values $(0.1$ and 0.001) gave identical results, which shows that the estimated parameters are robust. Instead of the $\mathrm{R}^{2}$ usually obtained by OLS, MLE yields the standard error of the equation, $\hat{\sigma}_{\varepsilon_{1}}$ which has the same unit as the dependent variable, as a goodness-of-fit. The lower $\hat{\sigma}_{\varepsilon}$ is, the better the fit (Kennedy 1992). STATISTICA 5.0 (StatSoft $^{*}$ 1994) was used to obtain a non-linear weighted estimation of the dependency between temperature and digestion velocity.

\section{RESULTS}

The percentage of prey retrieved declined slightly with increasing temperature and time. In Experimental Series 1 and $2\left(5.9\right.$ and $\left.8.1^{\circ} \mathrm{C}\right) 99.7$ and $99.1 \%$ of the gobies given to the cod in each tank were recorded during the gastric lavage. In Experimental Series 3 and $4\left(10.1\right.$ and $\left.12.4^{\circ} \mathrm{C}\right) 98.1$ and $94.8 \%$ were retrieved in total. After discarding trials with less than $95 \%$ recapture ( 3 trials), the respective values for the 10.1 and $12.4^{\circ} \mathrm{C}$ experiments were 98.8 and $98.6 \%$.

A total of 559 observations of weight of prey remaining $\left(W_{t}\right)$ for individual fish at time $t$,where $t$ is 2 to $24 \mathrm{~h}$, were obtained from the 4 experimental series (Table 6). Experimental Series 1 and 2 tend to have a higher number of observations at the lower meal sizes, while Experimental Series 3 and 4 had most observations distributed around the 6-prey meal size. The observations at the 10-prey group in Experimental Series 1 and 2, and at the 1-prey group in Experimental Series 3 , failed to provide a basis for estimations of the digestion velocity for cod in these groups. There was a weak tendency in the data that large cod took larger meals (Spearman-Rank correlation, $\mathrm{r}=0.31, \mathrm{p}<0.05$ ).

The error terms for all MLEs were found to be normally distributed (Kolmogorov-Smirnov test, $0.142<\mathrm{p}$ $<0.316$; Appendix 1). This fulfils the basic assumption of MLE.

Individual cod ate between 0 and 21 gobies. Empty stomachs were excluded from the analysis of digestion as they were not expected to bias digestion velocity parameters. Initial meal size was estimated from the mean weight of gobies in each trial times the number of gobies taken by each fish. The maximum meal size recorded, relative to body weight, was $8.89 \%$.

\section{Course of digestion}

The results of Experimental Series $1\left(5.9^{\circ} \mathrm{C}\right)$ are presented in Fig. 2, together with the gastric emptying

Table 6. An overview of the number of observations of $W_{t}$ obtained in the 4 experimental series. Observations in parentheses were not analyzed nor included in the total number

\begin{tabular}{|lcccccccccccc|}
\hline \multicolumn{1}{l}{$\begin{array}{l}\text { Experimental } \\
\text { series }\end{array}$} & \multicolumn{1}{c|}{$\begin{array}{c}\text { Number of gobies } \\
\text { (meal size) }\end{array}$} \\
& 1 & 2 & 3 & 4 & 5 & 6 & 7 & 8 & 9 & 10 & \\
\hline 1 & 23 & 22 & 20 & 18 & 24 & 11 & 17 & 13 & 5 & $(3)$ & 153 \\
2 & 12 & 18 & 8 & 10 & 13 & 13 & 16 & 8 & 6 & $(3)$ & 104 \\
3 & $(3)$ & 10 & 13 & 20 & 25 & 33 & 26 & 19 & 15 & 12 & 173 \\
4 & 8 & 9 & 9 & 13 & 21 & 10 & 20 & 16 & 15 & 8 & 129 \\
Total & 43 & 59 & 50 & 61 & 83 & 67 & 79 & 56 & 41 & 20 & 559 \\
\hline
\end{tabular}



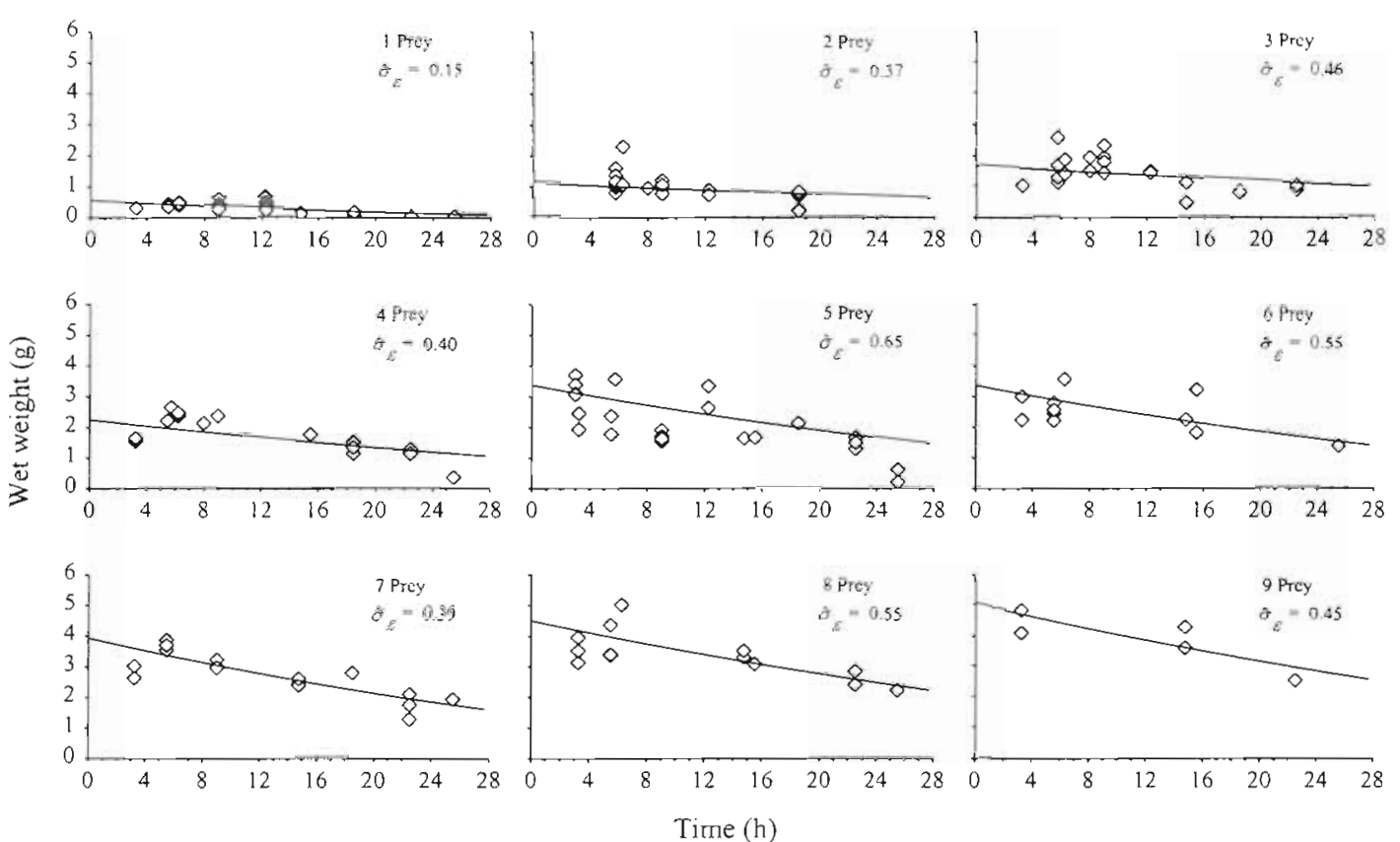

Fig. 2. Wet weight of different sized meals ( 1 to 9 prey) of two-spotted gobies, as a function of time $(t)$ after ingestion in the stomach contents of juvenile cod at $5.9^{\circ} \mathrm{C}$. Estimated $d_{\mathrm{s}}$ values for each meal size are given in Appendix 1. Solid line: model predicted course of digestion; $\dot{\sigma}_{\varepsilon}$ : standard error of the equation
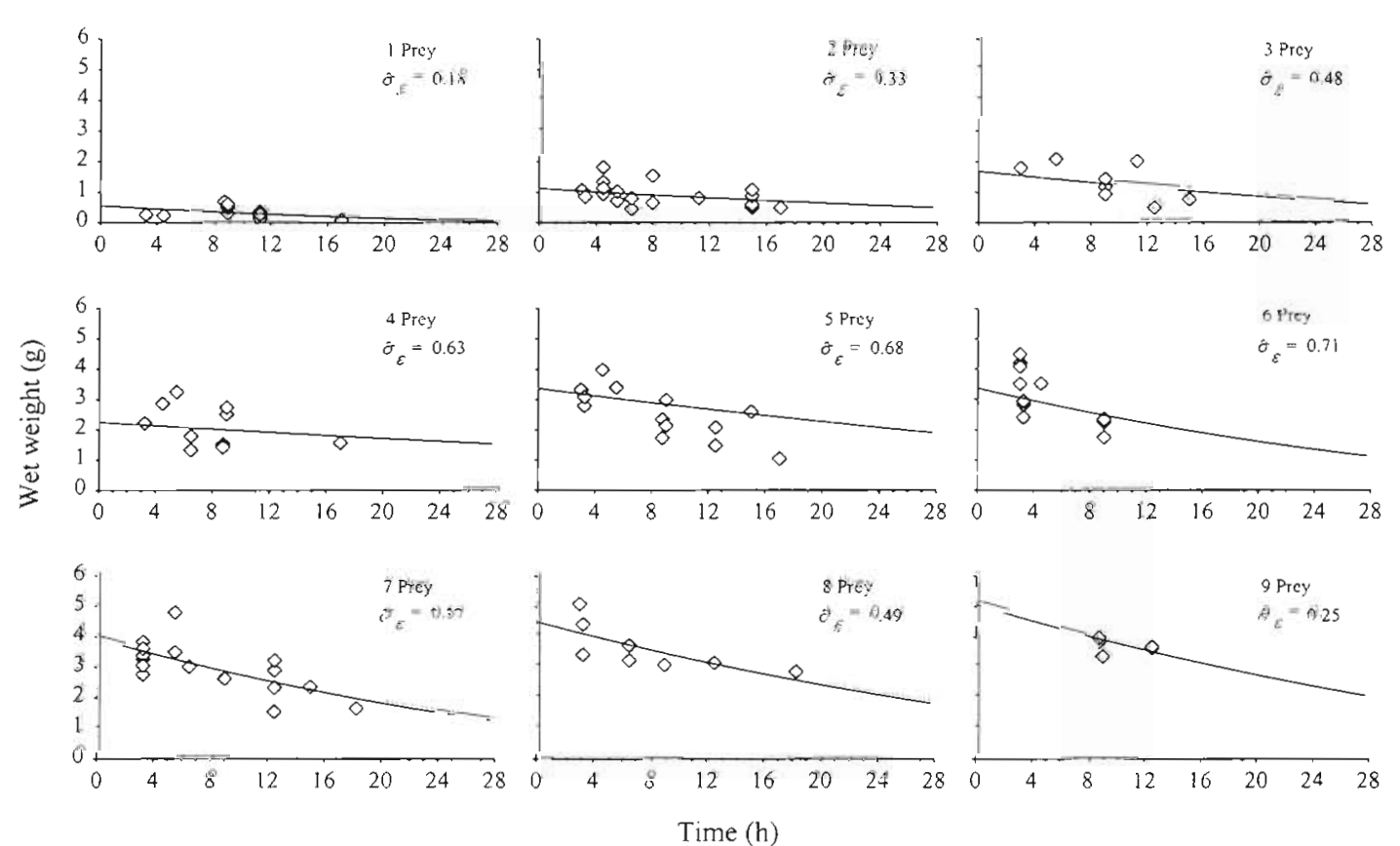

Fig. 3. Wet weight of different sized meals ( 1 to 9 prey) of two-spotted gobies, as a function of time $(t)$ after ingestion in the stomach contents of juvenile cod at $8.1^{\circ} \mathrm{C}$. Estimated $d_{c}$ values for each meal size are given in Appendix 1 Solid line: model predicted course of digestion; $\bar{\sigma}_{\varepsilon}$ : standard error of the equation

curve predicted by the model. The estimated values for $d_{\mathrm{s}}$ by meal size are provided in Appendix 1. Each data point represents the remaining stomach contents from 1 fish. Data points along the time axis represent observations from different trials, but of equal meal size. The results from each trial are thus distributed over the graphs according to how many prey each cod took.

The results from Experimental Series $2\left(8.1^{\circ} \mathrm{C}\right)$ and the predicted digestion pattern are given in Fig. 3. Following the digestion of a given meal size, e.g. 5 prey, 

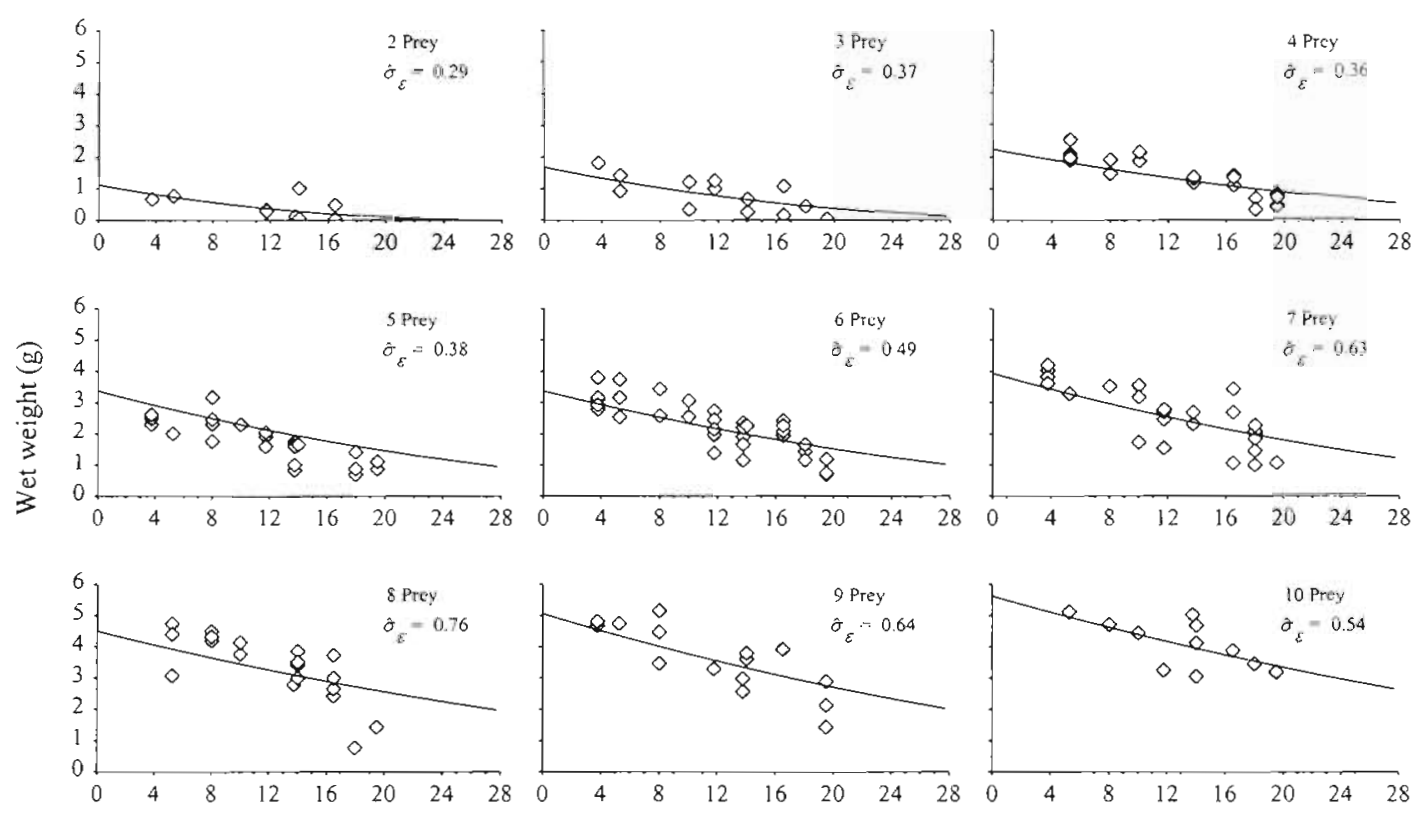

Time (h)

Fig. 4. Wet weight of different sized meals ( 2 to 10 prey) of two-spotted gobies, as a function of time (t) after ingestion in the stomach contents of juvenile cod at $10.1^{\circ} \mathrm{C}$. Estimated $d_{5}$ values for each meal size are given in Appendix 1 Solid line: model predicted course of digestion; $\hat{\sigma}_{\mathrm{e}}$ : standard error of the equation.

the model predicted that after $4 \mathrm{~h}$ only $8 \%$ of the meal was digested at $8.1^{\circ} \mathrm{C}$. After $12 \mathrm{~h}$ the digestive enzymes would have worked their way through $22 \%$, and by $24 \mathrm{~h} 41 \%$ of the original meal was digested. In the 6-prey group the estimations are based on the initial stages of digestion due to lack of observations beyond $9 \mathrm{~h}$ digestion time. A similar case is observed in the 9-prey group which resulted in only 6 observations, still the fit of the model predicted digestion is $\operatorname{good}\left(\hat{\sigma}_{\varepsilon}=0.25\right)$.

At $10.1^{\circ} \mathrm{C}$, a meal size of 5 prey was reduced by $40 \%$ after $12 \mathrm{~h}$, according to the surface model predictions of Experimental Series 3 (Fig. 4). A small meal size, e.g. 2 prey, was after the same amount of time reduced by $67 \%$, while only $26 \%$ of a large meal such as 10 prey was digested. These percentages correspond to 0.75 , 1.13 and $1.46 \mathrm{~g}$ digested for the 2-, 5- and 10-prey groups, respectively.

Data and model predicted digestion from Experimental Series 4 shows that digestion was increased at $12.4^{\circ} \mathrm{C}$ compared to the lower temperatures. Both the 1 - and 2-prey meals were fully digested (100\%) within $24 \mathrm{~h}$ of ingestion (Fig. 5). A meal size of 5 prey was reduced by $18 \%$ after $4 \mathrm{~h}$, by $47 \%$ after $12 \mathrm{~h}$ and $78 \%$ after $24 \mathrm{~h}$. For comparison, at $8.1^{\circ} \mathrm{C}$, only half of the same meal size was digested after the same time intervals. This demonstrates a clear temperature effect upon prey digestion and that digestion velocity is higher at higher temperatures.

\section{Meal size}

Fig. 6 shows for the 4 experimental temperature regimes the estimated values for digestion velocity $d_{s}$ and corresponding $95 \%$ confidence interval (CI) versus meal size, which reflects the number of gobies consumed per trial. The values shown for $d_{\mathrm{s}}$ are the same as those used to express the predicted wet weight of prey remains as a function of time after consumption seen in Figs. 2 to 5.

The confidence limits (CL) of the mean estimated $d_{\mathrm{s}}$ values at $5.9^{\circ} \mathrm{C}$ overlap in all cases but 2 (Fig. 6a). The lower limit for the 7 -prey group was slightly higher than the upper CL of the 2-and 3-prey groups. Nevertheless, the overall tendency suggests that a common $d_{\mathrm{s}}$ may be used to express how fast enzymes penetrate inwards the prey bolus. The same tendency as at $5.9^{\circ} \mathrm{C}$ is found at $8.1^{\circ} \mathrm{C}$ (Fig. 6b). There is a larger individual variation depicted by the wider $\mathrm{CL}$ and consequently all the CIs overlap. The mean digestion velocity for the 4 -prey group, however, is not significantly different from zero. This may result from the low number of observations made above $9 \mathrm{~h}$ of digestion (Fig. 3, 4 prey). The distribution of the mean digestion velocity at $10.1^{\circ} \mathrm{C}$ approximates a straight line (Fig. 6c). All CIs overlap and thus the digestion velocity can be represented by one common $d_{\mathrm{s}}$ value. At $12.4^{\circ} \mathrm{C}$, there is a tendency for the digestion velocity to be higher if cod ate 1 or 2 prey (Fig 6d). The lower CL for the 2-prey 

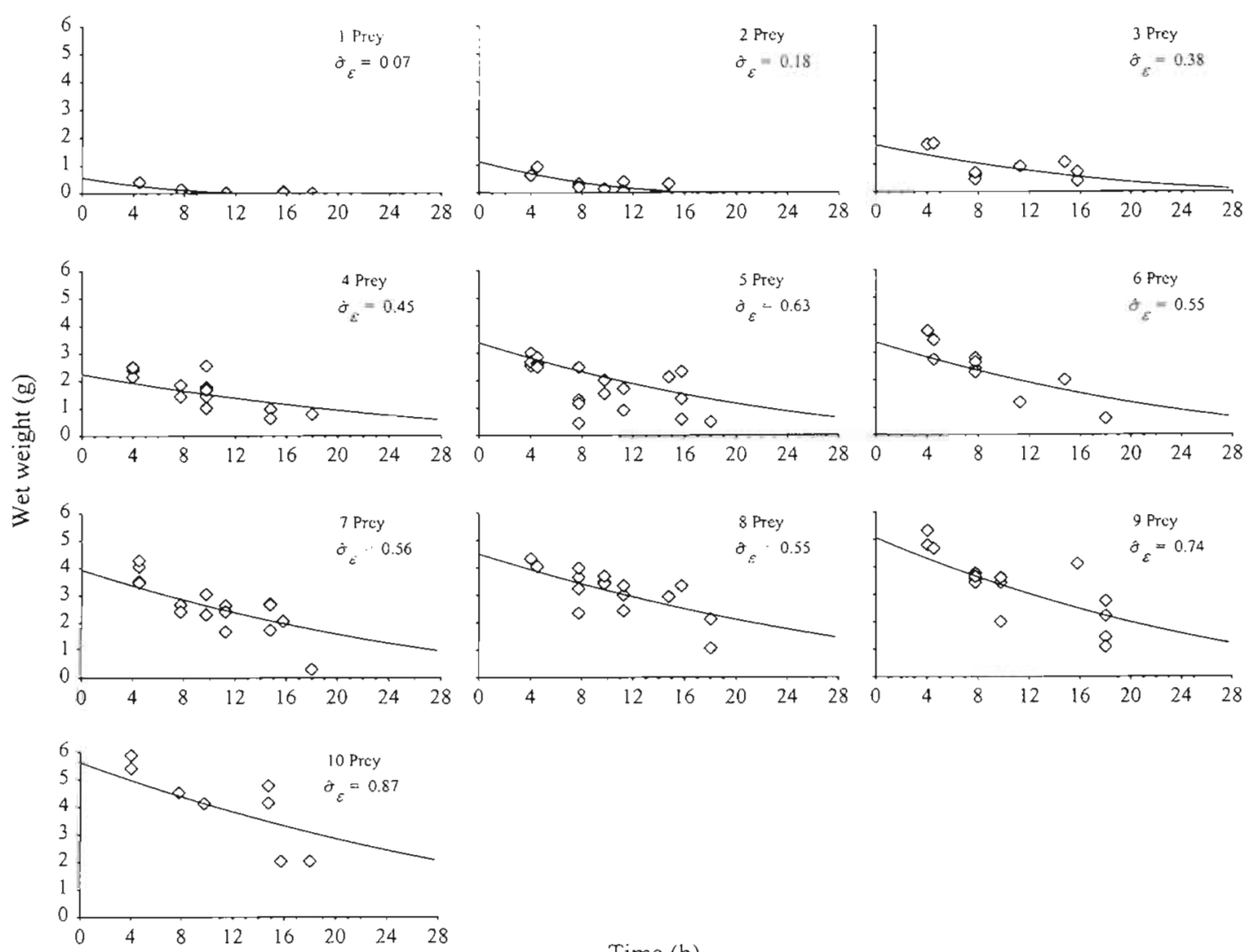

Time (h)

Fig. 5. Wet weight of different sized meals (1-10 prey) of two-spotted gobies, as a function of time $(t)$ since ingestion in the stomach contents of juvenile cod at $12.4^{\circ} \mathrm{C}$. Estimated $d_{\mathrm{s}}$ values for each meal size are given in Appendix 1 . Solid line: model predicted course of digestion; $\hat{\sigma}_{\varepsilon}$ : standard error of the equation

group has a slightly higher value $\left(0.0129 \mathrm{~cm} \mathrm{~h}^{-1}\right)$ than the upper CL for the 4 - and 8-prey groups (0.0119 and $0.0125 \mathrm{~cm} \mathrm{~h}^{-1}$ ). The $d_{\mathrm{s}}$ for the other meal sizes all have overlapping $\mathrm{Cls}$, and therefore are not significantly different from each other. A slight decline in the estimated digestion velocity over the first 3 or 4 meal sizes, although not significant, can also be seen in Fig. $6 \mathrm{~d}$.

The weak trend of increasing digestion velocity with meal size which can be distinguished in Fig. 6a,b and the weak trend of decreasing velocity in Fig. $6 \mathrm{c}$, d could be due to processes not specified by the surface model. However, because identification of processes other than those specified by the model was beyond the

Table 7. Weighted mean digestion velocity at each experimental temperature with $95 \%$ confidence limits (CL)

\begin{tabular}{|lccc|}
\hline Temp. $\left({ }^{\circ} \mathrm{C}\right)$ & $d_{\mathrm{s}}\left(\mathrm{Cm} \mathrm{h}^{-1}\right)$ & lower CL & upper CL \\
\hline 5.9 & 0.0056 & 0.0054 & 0.0059 \\
8.1 & 0.0067 & 0.0062 & 0.0072 \\
10.1 & 0.0094 & 0.0092 & 0.0097 \\
12.4 & 0.0119 & 0.0117 & 0.0121 \\
\hline
\end{tabular}

scope of our analysis, and since there were large overlaps in the $95 \%$ CI for the estimated parameters within the meal size range of 1 to 10 gobies, we found a weighted mean digestion velocity (weighted with the number of observations) estimated at each temperature to be a realistic expression for the velocity at which digestion enzymes penetrate progressively deeper into an ingested prey or prey bolus (Table 7 ).

\section{Temperature, $Q_{10}$ relation and $d_{s 0}$}

The surface model incorporates the temperature dependency of enzymatic processes through Eq. (3). Each separate estimate of $d_{\mathrm{s}}$ is plotted against the experimental temperatures to obtain a relationship between digestion velocity and temperature (Fig. 7). This relationship is expressed through the $Q_{10}$ parameter, which expresses the increase in rate per $10^{\circ} \mathrm{C}$ increase. The non-linear regression technique was applied to $d_{s}$ versus temperature. Each $d_{\mathrm{s}}$ was weighted with $\sqrt{\mathbf{n}}$ (where $\mathrm{n}=$ number of observations at each temperature which each $d_{\mathrm{s}}$ estimate is based upon) to account for the varying 

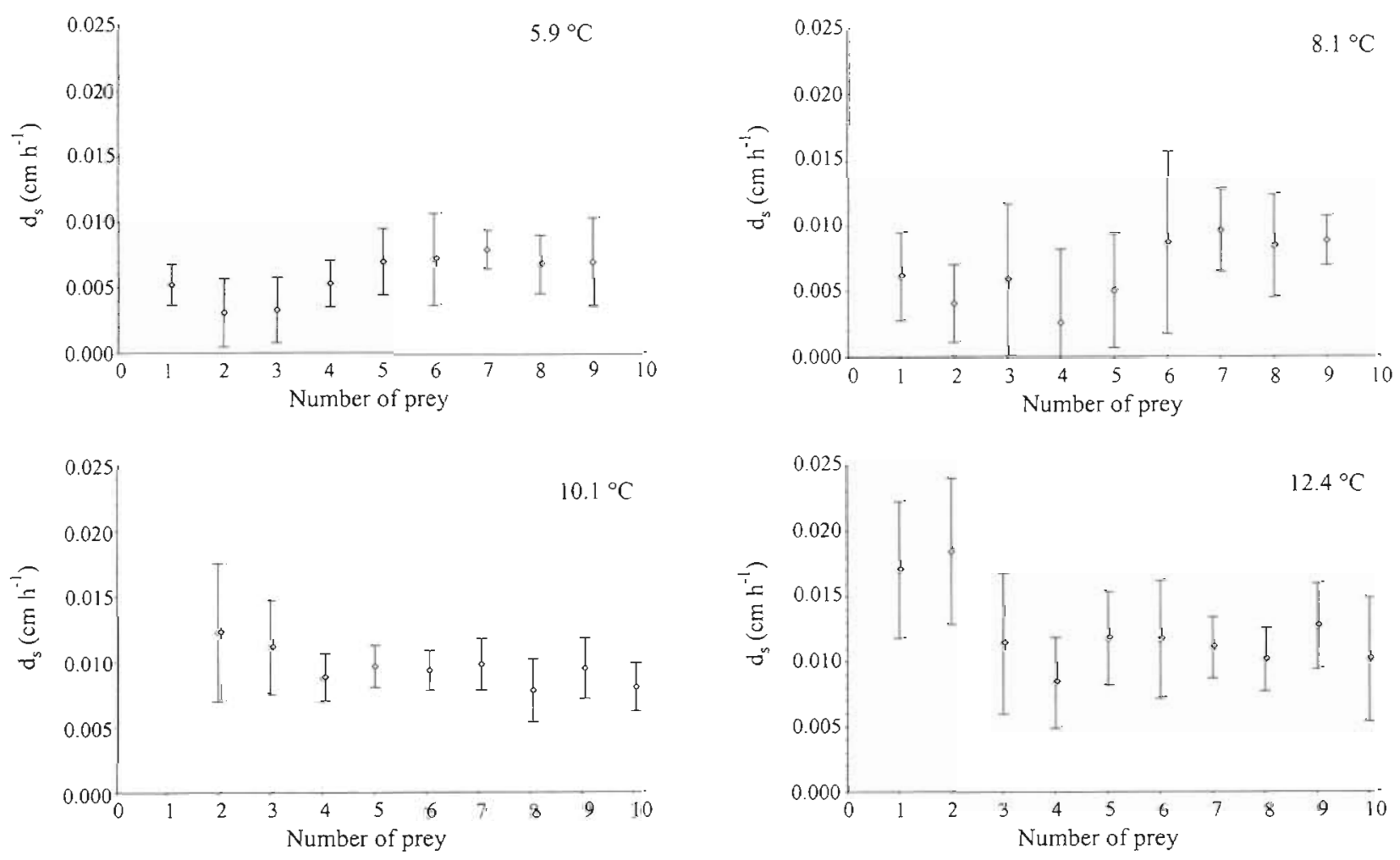

Fig. 6. Estimated mean digestion velocity, $d_{s}$, at $5.9(\mathrm{SE}=0.1), 8.1(\mathrm{SE}=0.2), 10.1(\mathrm{SE}=0.1)$ and $12.4^{\circ} \mathrm{C}\left(\mathrm{SE}=0.3^{\circ} \mathrm{C}\right)$ as a function of meal size. Vertical bars: $95 \%$ confidence interval

numbers of observations (Table 7). Weighting affected mainly the CL of the estimated curve while the intersect and gradient of the curve were largely unaffected.

The $d_{\mathrm{s} 0}$ is represented by the zero intersect of the temperature dependency indicated by the fitted exponential curve in Fig. 7 . The value $0.0026 \mathrm{~cm} \mathrm{~h}^{-1}(95 \%$ CI 0.00257-0.00261) thus expresses the digestion velocity $d_{s 0}$ at $0^{\circ} \mathrm{C}$. The estimated parameter expressing the power of the exponential curve $(0.123 \pm 0.013)$, calculated by solving $a=\ln \left(Q_{10}\right) / 10$ of Eq. (3) with respect to $Q_{10}$, gave $Q_{10}=3.41$ (95\% CI 2.64-4.43).

The digestion handling time $\left(t_{\max }\right)$ predicted from the estimated digestion velocities, can be found by solving for $t_{\max 2}$ in Eq. (5). Predicted results for the 4 experimental temperature groups are shown in Fig. 8. Digestion handling time increased with increasing prey bolus size and decreased as the temperature rose. At $6^{\circ} \mathrm{C}, 1-, 5$ - and 10 -goby meals were fully digested after $47.3,105.7$ and $149.4 \mathrm{~h}$, respectively. At $12^{\circ} \mathrm{C}$, the process was complete after $24.7,55.1$ and $77.8 \mathrm{~h}$, faster than at $6^{\circ} \mathrm{C}$ for the same meal sizes. For larger meal sizes, $t_{\text {max }}$ levels off by the same factor as radius increases with bolus size.

The daily feeding rates of fish are often predicted under the assumption that the rates of feeding and digestion, on average, counterbalance each other. The amount digested $(\mathrm{g})$ after $24 \mathrm{~h}$ depends on the size of the meal and on the temperature. Depending on whether the cod was surrounded by 6 or $12^{\circ} \mathrm{C}$ water, the surface model predicts that a $75 \mathrm{~g}$ cod which takes a 1 -prey meal digested 0.6 or $0.8 \%$ of its own body weight per day ( 77.3 or $100 \%$ of the prey). For 10 prey, the corresponding values were 2.5 and $4.6 \%$ of its own body weight per day ( 34.0 or $61.7 \%$ of the prey).

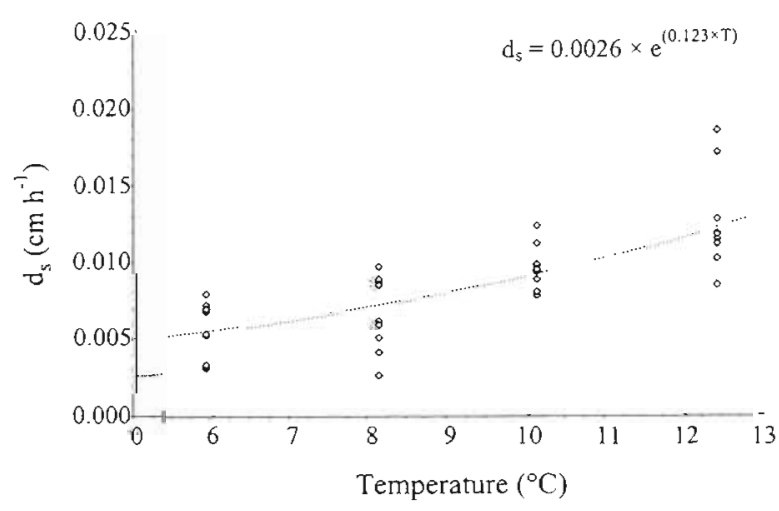

Fig. 7. Estimated digestion velocity for each meal size as a function of temperature. The fitted exponential function is based on each single estimate of $d_{s}$ and weighted with the square root of the number of observations for each prey group $\left(\mathrm{R}^{2}=0.57, \mathrm{n}=37\right)$ 


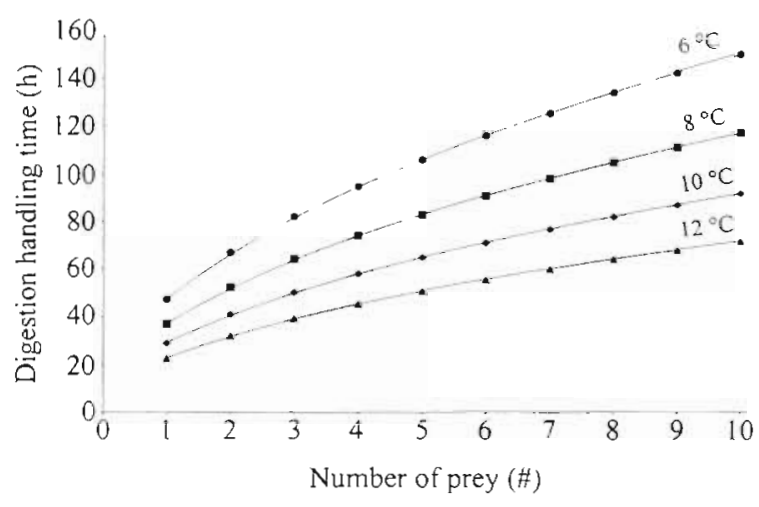

Fig. 8. Predicted digestion handling time $t_{\max }$ for increasing meal size at 6 to $12^{\circ} \mathrm{C}$. Lines are for visualizing trends and are fitted by least square estimation

\section{Evaluation of surface model}

The surface-dependent digestion model gives similar goodness of fit to the data as empirical models such as the linear, exponential and square root estimations. Two cases are shown in Fig. 9, illustrating approximate linear and exponential patterns. In Fig. 9a the models have an almost identical fit, even though the predictions diverge somewhat towards the later phases of digestion. In Fig. 9b the differences are more pronounced, with the linear model being the least descriptive

The surface-dependent digestion model requires elaborate information on the prey, and may therefore fall short when calculating back to the initial meal size, especially if one has limited information about prey populations. However, estimating individual initial meal sizes does not seem to be within the capacity of the conventional models either, as long as $t$ remains unknown, so the surface-dependent digestion model is no less useful than any other digestion model. In a modelling context or when estimating the digestion handling time of a specific prey type, the surfacedependent digestion model may be superior to other digestion models, especially if prey choice and feeding behaviour are considered. Initial information on size distribution is attainable for commercially important prey species (e.g. SPECIESDAB, SHRDATA, IPTP ${ }^{1}$ ), and can be used as input parameters for predatorprey models. The surface-dependent digestion model may therefore be useful for multispecies assessment models.

${ }^{1}$ SPECIESDAB is a global species database for fishery purposes (Fish. Dep. FAO, Rome, Italy). SHRDATA is a database for research survey and commercial fishery data on Scotian Shelf shrimp (Dep. Fish. Oceans, Halifax, Canada). The IPTP data catalogue contains tuna fisheries information (FAO, Colombo, Sri Lanka)
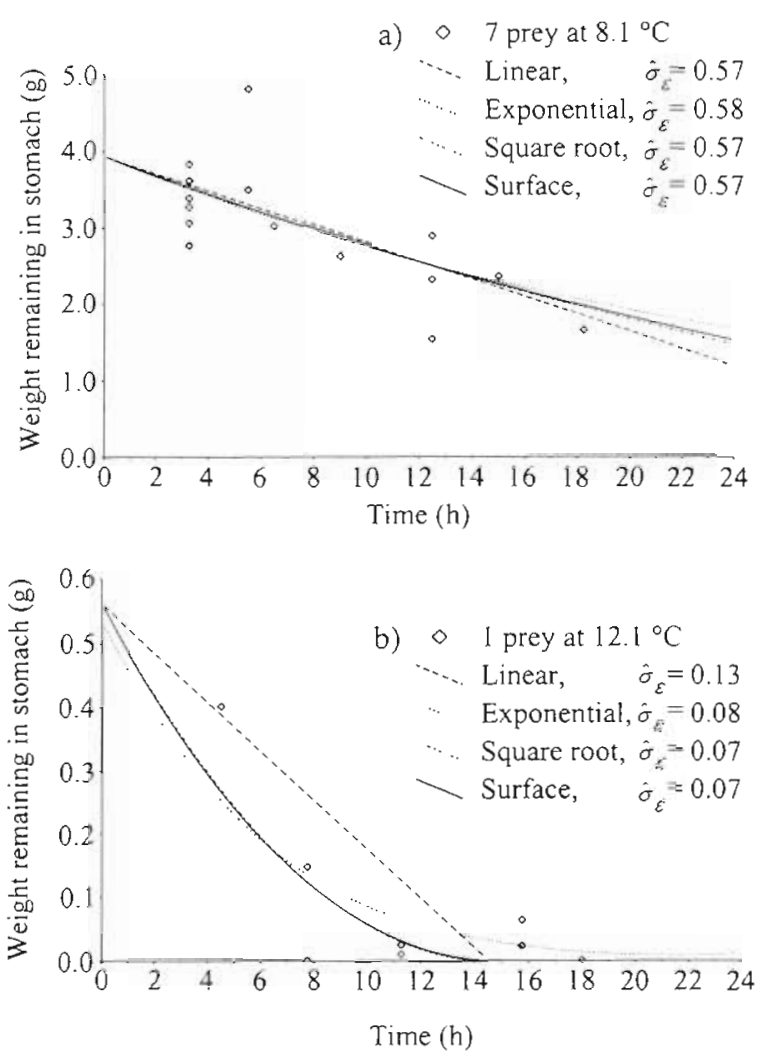

Fig. 9. Predicted digestion and fit $\left(\hat{\sigma}_{\varepsilon}\right)$ of 4 different digestion models to the data of (a) 7-goby meal size at $8.1^{\circ} \mathrm{C}$ and (b) $1-$ goby meal size at $12.4^{\circ} \mathrm{C}$. Diamonds represent actual data, while lines show the predicted digestion pattern by the respective models. Note the difference in the $y$-axis scale between ( $a$ ) and ( $b$ )

\section{Potential effect of prey digestibility on prey choice}

The simulated scenarios of prey choice using the classical approach (Table 8a) and by accounting for digestion (Table $8 \mathrm{~b}$ ) gave different predictions. Prey type 1 refer to the two-spotted goby and the handling time associated with digestion $H_{d}$ is based on the estimated digestion velocity for $12^{\circ} \mathrm{C}$ from the present study. Values for the handling time $H$ from prey encounter until ingestion originate from experiments of Steingrund \& Fernø (1997). For ease of comparison, the parameters for the other prey types are chosen relative to those for the two-spotted goby. For simplicity, we assumed the same encounter rate for all prey types and $H_{d}=0.2$. $I_{0 j} / d_{s j}$, thus allowing the fish to resume feeding before the entire prey or prey bolus is digested. It is shown in the simulations that the incorporation of digestion can alter predicted optimal diet as compared with predictions from the classical approach which does not account for digestion (Table 8 ). The diet breadth became also more narrow, and it was shown that an optimal predator should prefer prey with high digestibility. 
Table 8. Illustration of how prey digestibility may alter rank of prey choice in cod. Parameters for the smallest prey refer to twospotted goby and digestion at $12^{\circ} \mathrm{C}$. W: g wet weight of prey which is assumed to be proportional to energetic contents. To demonstrate effect of prey digestion an identical encounter rate for all prey $\left(1 \mathrm{prey}^{-1}\right)$ is assumed. Parameters for other prey are chosen relative to gobies. (a) Predictions from the classical approach; (b) predictions when digestion handling time is accounted for. Handling time until fish resumed feeding was set proportional to the digestion handling time and as $H_{d j}=0.2 t_{\mathrm{max}}=0.2\left(r_{0} / d_{5 j}\right)$

\begin{tabular}{|c|c|c|c|c|c|c|c|}
\hline \multicolumn{2}{|c|}{$\begin{array}{l}\text { (a) Classical approach } \\
W\end{array}$} & $H(\mathrm{~h})$ & \multicolumn{2}{|r|}{$W / H$} & Rank & $\sum_{j=1}^{j=p^{-1}} \lambda_{j}\left(W_{j}-W_{p} H, / H_{p}\right)$ & Include in diet? \\
\hline 4 & & 0.022 & & 180.0 & 1 & & Yes \\
\hline 16 & & 0.092 & & 174.5 & 2 & 0.9 & Yes \\
\hline 8 & & 0.056 & & 144.0 & 3 & 10.8 & Yes \\
\hline 2 & & 0.017 & & 120.0 & 4 & 34.4 & Yes \\
\hline 1 & & 0.011 & & 90.0 & 5 & 244.0 & No \\
\hline \multicolumn{8}{|c|}{ (b) Incorporating effect of digestion } \\
\hline W & $H(\mathrm{~h})$ & $r_{0}(\mathrm{~cm})$ & $d_{s /}\left(\mathrm{cm} \mathrm{h}^{-1}\right)$ & $W /\left(H+H_{d j}\right)$ & Rank & $\sum_{j=1}^{j=1} \lambda_{j}\left(W_{j}-W_{p} \frac{H_{j}+H_{d j}}{H_{p}+H_{d p}}\right)$ & Include in diet? \\
\hline 2 & 0.017 & 0.56 & 0.014 & 2.0 & 1 & & Yes \\
\hline 8 & 0.056 & 0.87 & 0.004 & 1.7 & 2 & 0.3 & Yes \\
\hline 16 & 0.092 & 0.98 & 0.002 & 1.5 & 3 & 1.3 & Yes \\
\hline 1 & 0.011 & 0.45 & 0.011 & 1.0 & 4 & 9.7 & No \\
\hline 4 & 0.022 & 0.62 & 0.002 & 0.5 & 5 & 18.4 & No \\
\hline
\end{tabular}

\section{DISCUSSION}

\section{Digestion handling time, motivation for feeding and prey choice}

The digestion handling time would depend on the size of an ingested meal (Fig. 8), which in turn is proportional to the thickness of the prey or prey bolus (Salvanes et al. 1995). If different kinds of prey are eaten by a fish, they are likely to be digested at different velocities (e.g. Jones 1974). Planktivores usually take a large number of small prey, while piscivores concentrate their food intake on a small number of large prey. The handling time of prey in planktivores may set a limit to the number of prey taken per day (Giske \& Salvanes 1995), while piscivores are assumed to be limited by stomach capacity and digestion constraints (Jobling 1982, Breck 1993). Fig. 10 illustrates 3 hypothetical scenarios of stomach filling as a function of time for a predator, supported by findings of Grove et al. (1985). The first (Fig. 10a) could represent the stomach filling curve for juvenile cod which live in the sublittoral, where it primarily takes prey from shoals of gobies (Godø et al. 1989, Fosså 1991, Salvanes \& Noreide 1993). A large predator which takes various kinds of prey (e.g. fish and crustaceans) could be represented by the scenario in Fig. 10b. Fig. 10c illustrates the stomach filling of a frequently feeding planktivore, such as juvenile pink salmon Oncorhynchus gorbuscha Walbaum, which resumes feeding after as little as $15 \%$ stomach evacuation (Godin 1981). The habitat of the predator determines, of course, which prey are available. Since the return of appetite would be directly related to the digestion handling time of a meal (Grove et al. 1978), it is likely that the prey a fish consumes and its different digestion velocities affect future choice of prey. If the prey taken are digested slowly, the fish may either wait for a longer time than if more easily digested prey are taken before resuming feeding or resume feeding again earlier but take smaller prey.

Optimal foraging theory (OFT) states that within the range of possible behaviour, animals will act in ways that maximise their fitness (Pyke 1979). Applied to prey selection, OFT has emphasised the cost-benefit ratio of energy intake. Diet is determined not only by the nutritional value of a prey, but also by the energetic and time cost of handling. The optimum can be found by determining the diet that maximises the net rate of energy gain.

Handling time of prey is not static. Filling of the stomach and decreased hunger level increases the handling
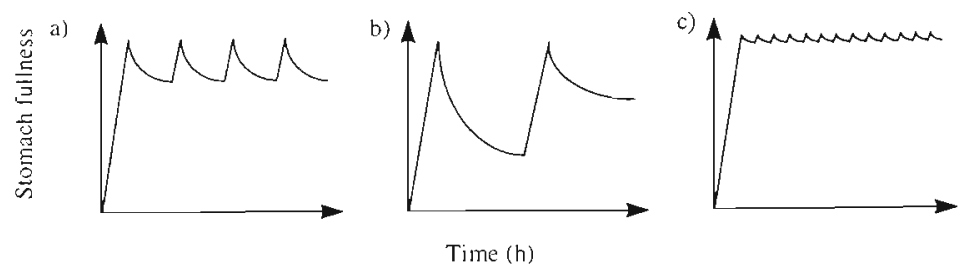

Fig. 10. Theoretical stomach fullness for a predator which initially has a full stomach and then subsequently take (a) multiple small prey, (b) a few large prey of different contents or (c) a planktivore diet as stomach space becomes available by the predicted digestion pattern 
time (Street et al. 1984, Bindoo \& Aravindan 1992), while experience acts to reduce handling time (Kislalioglu \& Gibson 1976). It has been observed in juvenile cod that if an individual is close to satiation, a prey may be taken and spat out many times in a row before it is swallowed. It has also been observed that fish that do accept prey until satiation on one day would be less motivated to consume prey the next day - possibly due to digestion constraints (Salvanes unpubl.).

Conventional definitions of handling time may be based on the difference in size order of units between handling and digestion. Handling time in bluegill sunfish when eating natural prey (Daphnia magna Straus) is on the order of seconds to a few minutes (Werner 1974), while the time required to digest a corresponding meal of aquatic insect larvae (Chironomus sp., Lumbricus sp. and others) is on the order of hours to days (Windell 1966). A similar relation also applies to cod, for which the handling time of two-spotted gobies is within minutes (Steingrund 1993, Steingrund \& Fernö 1997) when the individuals are not digestion limited, while digestion of the same prey has been shown in the present study to take considerably longer (although depending on temperature) (Fig. 8). It is hard to imagine that only seizure and swallowing should determine the profitability of the prey when digestion constitutes such a large part of the handling time. The simulated scenarios of prey choice using the classical approach (Table 8a) and by the approach outlined here which accounts for digestion (Table $8 \mathrm{~b}$ ) give different predictions. The ranks of available prey change considerably if digestion is accounted for. It was also predicted that a more narrow optimal diet breadth exists and that an optimal predator should prefer prey which are digested rapidly over those digested at slower rates (Table 8).

\section{Factors affecting digestion}

In the previous section we concluded that prey digestion must affect prey choice. In addition we wish to point out the large number of factors that affect digestion, and which then must indirectly affect prey choice. Prey characteristics such as chemical composition, size, and freshness affect the time required for it to be digested (Fänge \& Grove 1979, Bromley 1994), but the rate of metabolic processes in poikilotherms is also largely dependent on temperature and this is reflected in the digestion time in fish (Kapoor et al. 1975, Windell 1978, Jobling 1994).

Piscivorous fish do not generally chew their prey (Moyle \& Cech 1988) and consequently the digestive enzymes have to attack the periphery of the prey. Cod capture prey by suction (Fuiman \& Batty 1994) and digest their prey whole (Danulat 1987, Ellis \& Gibson 1997), which is in agreement with our use of the surface-dependent digestion model of Salvanes et al. (1995) in this study. Several other authors have stated the surface area dependency of the digestion process (Tyler 1970, Daan 1973, Swenson \& Smith 1973, Bagge 1977. Grove et al. 1985, Persson 1986, Bromley 1991, dos Santos \& Jobling 1991b) and some have also treated it as such (Fänge \& Grove 1979, Grove et al. 1985, Macpherson et al. 1989, dos Santos \& Jobling 1992). However, in their models the process was fitted as a power function and not formulated as a function of prey geometry a priori, so the parameters estimated had limited biological meaning

\section{Meal size}

Meal size affects enzymatic action indirectly through the ratio of enzymes to surface area. Upon initial consideration, multiple similar sized prey would seem to increase prey surface proportionally to prey volume, but prey items are not randomly stored in the stomach (Hart \& Gill 1992). For turbot fed various dry pellet sizes comprising constant meal size, the digestion rate tended to increase with pellet numbers per meal, which means that the pellets were not packed into a common surface in the fish stomach (Grove et al. 1985). The absence of packing could be due to low flexibility in dry pellets. Other studies which used natural prey like fish which are more flexible and therefore more easy to pack in a fish stomach report that the prey tended to be packed, leaving a common bolus shape accessible to digestion (dos Santos \& Jobling 1992, Salvanes et al. 1995). A large meal which consists of numerous prey may consist partly of single prey that have not yet been attacked by digestive enzymes after $24 \mathrm{~h}$ of digestion and partly of highly disintegrated prey (Karpevich \& Bokova 1937). This was also recorded in our study. If several prey were retrieved from one fish stomach soon after they were ingested, the prey tended to have been attacked by digestive enzymes at what could have been the common surface of the prey bolus, whereas the parts of the prey possibly representing the inner part of the bolus tended to have been attacked less by enzymes.

The assumption of a constant digestion velocity in the surface-dependent digestion model implies a constant relation between enzyme concentration and area of prey or prey bolus surface. This is expected to be valid for both smail and large meal sizes, since gastric distension stimulates secretion of gastric juices (Smit 1967) and thereby increases the enzyme supply during the intake of large meals. As digestion proceeds, the enzyme concentration might be expected to increase 
because the surface area shrinks when the prey diminishes. However, the co-occurring depletion of chyme from the stomach during digestion (Tyler 1970), and reduced activity of enzymes towards the later digestive phase (Norris et al. 1973), may counterbalance this. We estimated a common digestion velocity for all meal sizes, but different velocities for different temperatures, since there was a pronounced overlap of the $95 \% \mathrm{CI}$ for most of the estimated digestion velocities over all meal sizes. The effect of meal size on digestion handling time is clearly that digestion handling time increases with increases in meal size (Fig. 8) despite the fact that digestive enzymes work progressively inwards into a prey bolus at a constant rate. Since the return of appetite is directly related to the digestion handling time of a meal (Grove et al. 1979), it is likely that the meal size taken previously by a predator will affect future prey choice.

\section{Predator size}

Small fish have a relatively higher metabolic rate than large fish (Kapoor et al. 1975). Apparent differences in the alimentary tract morphology between juvenile and adult cod (Tyler 1973) also suggest digestion differences. Dos Santos \& Jobling (1991b) showed that, for a large cod size range ( 262 to $2066 \mathrm{~g}$ ), the size effects on digestion were closely counterbalanced by the effects of meal size, and that equal relative stimuli of the stomach wall caused the same responses (i.e. production of digestive enzymes) in cod of different sizes. It is therefore likely that the estimated parameters for juvenile cod obtained by the surface-dependent digestion model in the present study can be regarded as independent of predator size and thus also apply to adult cod.

\section{Prey type}

Lipid content reflects the amount of energy in a prey. High lipid content is known to retard the gastric evacuation process in fish (Windell 1978, Jobling 1981a, Bromley 1994), and also in other vertebrates (Quigley \& Meschan 1941). Earlier application of the surface model used the lipid-rich herring as prey (Salvanes et al. 1995). Gobiids are rather lean fish, with a reported energy content of $4.13 \mathrm{~kJ} \mathrm{~g}^{-1}$ wet weight for the bareyed goby Glossogobius giuris Hamilton (Sitaramaiah 1967). Species within the same genus have similar energy content (Cummins \& Wuycheck 1971). Assuming a similar calorie to wet weight ratio for the two-spotted goby as Sitaramaiah (1967) reported for the bar-eyed goby, the caloric content of two-spotted goby is $3.72 \mathrm{~kJ}$ $\mathrm{g}^{-1}$. This is similar to the value for cod flesh $\left(3.06 \mathrm{~kJ} \mathrm{~g}^{-1}\right)$, but clearly less than that for fish like herring $(7.91 \mathrm{~kJ}$ $\left.\mathrm{g}^{-1}\right)$ or mackerel Scomber scombrus L. $\left(9.14 \mathrm{~kJ} \mathrm{~g}^{-1}\right)$ (cf. Holland et al. 1993). The higher $d_{\mathrm{s} 0}$ estimated for gobies as compared to the $d_{50}$ which Salvanes et al. (1995) estimated for herring prey might therefore be ascribed to a lower lipid content in gobies than in herring.

\section{Temperature}

Temperature affects the digestion system in poikilotherms in several ways (Kapoor et al. 1975, Windell 1978, Jobling 1994). Energy requirements and activity increase with temperature (Jobling \& Hjelmeland 1992). In the stomach, the rates of both gastric acid secretion and pepsin secretion are influenced by temperature (Smit 1967, Moyle \& Cech 1988). The hydrolytic activity of digestive enzymes and the gastric and intestinal motility also increase with temperature (Jobling \& Hjelmeland 1992). The combined effect of these processes increases digestion velocity as temperature increases, and our results, which showed that the higher the temperature the higher $d_{\mathrm{s}}$, are consistent with this. The graph of $d_{\mathrm{s}}$ versus temperature shows an exponential pattern within the temperature range used in this study (Fig. 7). A similar tendency was also found for juvenile cod by Tyler (1970).

The temperature rate constant, $Q_{10}$, which expresses how strongly the digestion velocity depends on temperature, has been estimated for cod as 2.2 (Jones 1974), 2.8 (Jobling \& Hjelmeland 1992), 3.3 (Tyler 1970) and 10.3 (Salvanes et al. 1995). These values, except the latter, are within the range of what normally is considered to be the increase in rate following a $10^{\circ} \mathrm{C}$ temperature rise (Jobling \& Hjelmeland 1992 , Bromley 1994). The high $Q_{10}$ value obtained by Salvanes et al. (1995) were restricted by the authors for use only at temperatures below $6^{\circ} \mathrm{C}$ whereas the others were valid over a much larger temperature regime. The $Q_{10}$ of 3.4 obtained here for cod kept under the common seasonal temperature variations of west Norwegian waters is in good accordance with the findings of Tyler (1970), Jones (1974) and Jobling \& Hjelmeland (1992). The corresponding estimate of $d_{s 0}$ for coastal cod digesting two-spotted goby, $2.6 \times 10^{-3} \mathrm{~cm} \mathrm{~h}^{-1}$, was slightly higher than the $2.2 \times 10^{-3} \mathrm{~cm} \mathrm{~h}^{-1}$ which Salvanes et al. (1995) found for Arctic cod digesting herring prey. Compared to previous empirical gastric evacuation curves, which have a separate $d_{\mathrm{s}}$ for each temperature (Bagge 1977, Flowerdew \& Grove 1979, Booth 1990), the approximation made in our analysis represents a simplification and thus an improvement.

The effect of temperature on digestion is that digestion handling time decreases with increasing temperature for similar meal sizes (Fig. 8) due to increased 
enzymatic processes. Hence, similar sized meals disappear more rapidly from a fish stomach at high rather than at low temperatures. This will have an indirect effect upon prey choice since the return of appetite depends on how fast a prey is digested (Grove et al. $1979,1985)$. Hence, the fish may resume feeding earlier and so obtain higher feeding rates in a warm rather than in a cold season. Also, prey selection could differ between seasons because the constraints generated by digestion handling time would differ for different prey at different temperatures. Seasonal variations in temperature could in this way affect the prey choice of a fish predator and thus its diets in addition to the dependence on seasonally fluctuating prey abundance.

Appendix 1. Results of the surface-dependent digestion model estimations. Temp.: mean temperature used in the experiments. Estimated digestion velocity $d_{s}\left(\mathrm{~cm} \mathrm{~h}^{-1}\right)$, with $95 \%$ confidence limit $(\mathrm{CL})$ is based on number of observations (n) and the standard error $\left(\hat{\sigma}_{\varepsilon}\right)$. Kolmogorov-Smirnov test $(D)$ for normality of the error term. Unless $D$ was significant $(<0.05)$ the hypothesis of normal distribution could not be rejected

\begin{tabular}{|c|c|c|c|c|c|c|c|c|c|}
\hline Temp. & $\begin{array}{l}\text { Prey } \\
\text { eaten }\end{array}$ & $d_{s}$ & $\begin{array}{l}\text { Lower } \\
\text { CL }\end{array}$ & $\begin{array}{l}\text { Upper } \\
\text { CL }\end{array}$ & $\mathrm{n}$ & $\begin{array}{l}\text { Standard } \\
\text { error }\end{array}$ & $\hat{\sigma}_{\varepsilon}$ & $t$ & $D$ \\
\hline 5.9 & 1 & 0.0052 & 0.0036 & 0.0068 & 23 & 0.00075 & 0.1488 & 6.92 & 0.142 \\
\hline 5.9 & 2 & 0.0031 & 0.0005 & 0.0057 & 22 & 0.00125 & 0.3716 & 2.46 & 0.264 \\
\hline 5.9 & 3 & 0.0033 & 0.0008 & 0.0058 & 20 & 0.00119 & 0.4583 & 2.76 & 0.242 \\
\hline 5.9 & 4 & 0.0053 & 0.0035 & 0.0071 & 18 & 0.00084 & 0.4036 & 6.26 & 0.212 \\
\hline 5.9 & 5 & 0.0069 & 0.0044 & 0.0094 & 24 & 0.00122 & 0.6479 & 5.66 & 0.165 \\
\hline 5.9 & 6 & 0.0072 & 0.0037 & 0.0106 & 11 & 0.00156 & 0.5497 & 4.60 & 0.314 \\
\hline 5.9 & 7 & 0.0079 & 0.0064 & 0.0093 & 17 & 0.00069 & 0.3906 & 11.48 & 0.188 \\
\hline 5.9 & 8 & 0.0068 & 0.0045 & 0.0090 & 13 & 0.00101 & 0.5526 & 6.67 & 0.267 \\
\hline 5.9 & 9 & 0.0069 & 0.0036 & 0.0103 & 5 & 0.00121 & 0.4536 & 5.73 & 0.258 \\
\hline 8.1 & 1 & 0.0061 & 0.0027 & 0.0095 & 12 & 0.00153 & 0.1780 & 3.99 & 0.245 \\
\hline 8.1 & 2 & 0.0041 & 0.0011 & 0.0070 & 18 & 0.00141 & 0.3257 & 2.88 & 0.206 \\
\hline 8.1 & 3 & 0.0058 & 0.0000 & 0.0117 & 8 & 0.00246 & 0.4808 & 2.38 & 0.233 \\
\hline 8.1 & 4 & 0.0026 & -0.0031 & 0.0082 & 10 & 0.00249 & 0.6290 & 1.04 & 0.277 \\
\hline 8.1 & 5 & 0.0050 & 0.0007 & 0.0094 & 13 & 0.00199 & 0.6795 & 2.53 & 0.148 \\
\hline 8.1 & 6 & 0.0087 & 0.0017 & 0.0156 & 13 & 0.00318 & 0.7073 & 2.72 & 0.355 \\
\hline 8.1 & 7 & 0.0096 & 0.0065 & 0.0128 & 16 & 0.00148 & 0.5723 & 6.52 & 0.211 \\
\hline 8.1 & 8 & 0.0084 & 0.0045 & 0.0124 & 8 & 0.00166 & 0.4945 & 5.08 & 0.208 \\
\hline 8.1 & 9 & 0.0088 & 0.0070 & 0.0107 & 6 & 0.00074 & 0.2487 & 12.02 & 0.319 \\
\hline 10.1 & 2 & 0.0123 & 0.0070 & 0.0175 & 10 & 0.00232 & 0.2915 & 5.30 & 0.316 \\
\hline 10.1 & 3 & 0.0112 & 0.0076 & 0.0147 & 13 & 0.00164 & 0.3663 & 6.81 & 0.151 \\
\hline 10.1 & 4 & 0.0088 & 0.0070 & 0.0106 & 20 & 0.00087 & 0.3609 & 10.16 & 0.193 \\
\hline 1.0 .1 & 5 & 0.0097 & 0.0081 & 0.0113 & 25 & 0.00077 & 0.3833 & 12.55 & 0.145 \\
\hline 10.1 & 6 & 0.0093 & 0.0078 & 0.0108 & 33 & 0.00075 & 0.4925 & 12.43 & 0.155 \\
\hline 10.1 & 7 & 0.0098 & 0.0078 & 0.0117 & 26 & 0.00096 & 0.6274 & 10.20 & 0.173 \\
\hline 10.1 & 8 & 0.0078 & 0.0053 & 0.0102 & 19 & 0.00115 & 0.7571 & 6.75 & 0.217 \\
\hline 10.1 & 9 & 0.0094 & 0.0071 & 0.0118 & 15 & 0.00108 & 0.6354 & 8.74 & 0.178 \\
\hline 10.1 & 10 & 0.0080 & 0.0061 & 0.0099 & 12 & 0.00084 & 0.5425 & 9.49 & 0.186 \\
\hline 12.4 & 1 & 0.0170 & 0.0118 & 0.0222 & 8 & 0.00220 & 0.0702 & 7.73 & 0.301 \\
\hline 12.4 & 2 & 0.0184 & 0.0129 & 0.0240 & 9 & 0.00242 & 0.1815 & 7.63 & 0.195 \\
\hline 12.4 & 3 & 0.0114 & 0.0060 & 0.0168 & 9 & 0.00234 & 0.3797 & 4.87 & 0.213 \\
\hline 1.2 .4 & 4 & 0.0084 & 0.0049 & 0.0119 & 13 & 0.00160 & 0.4467 & 5.25 & 0.227 \\
\hline 12.4 & 5 & 0.0118 & 0.0082 & 0.0154 & 21 & 0.00173 & 0.6286 & 6.80 & 0.162 \\
\hline 12.4 & 6 & 0.0117 & 0.0072 & 0.0162 & 10 & 0.00200 & 0.5494 & 5.85 & 0.271 \\
\hline 12.4 & 7 & 0.0111 & 0.0087 & 0.0134 & 20 & 0.00112 & 0.5555 & 9.86 & 0.175 \\
\hline 12.4 & 8 & 0.0101 & 0.0077 & 0.0125 & 16 & 0.00111 & 0.5543 & 9.08 & 0.167 \\
\hline 12.4 & 9 & 0.0127 & 0.0094 & 0.0160 & 15 & 0.001 .53 & 0.7428 & 8.29 & 0.211 \\
\hline 12.4 & 10 & 0.0101 & 0.0054 & 0.0149 & 8 & 0.00201 & 0.8728 & 5.04 & 0.253 \\
\hline 0 & 1. & 0.0025 & 0.0020 & 0.0031 & 46 & 0.00025 & 0.1522 & 10.05 & 0.247 \\
\hline 0 & 2 & 0.0025 & 0.0019 & 0.0031 & 59 & 0.00031 & 0.3561 & 7.94 & 0.187 \\
\hline 0 & 3 & 0.0025 & 0.0019 & 0.0031 & 50 & 0.00030 & 0.4433 & 8.31 & 0.227 \\
\hline 0 & 4 & 0.0022 & 0.0018 & 0.0026 & 61 & 0.00020 & 0.4683 & 10.86 & 0.170 \\
\hline 0 & 5 & 0.0027 & 0.0023 & 0.0031 & 83 & 0.00021 & 0.5921 & 12.83 & 0.165 \\
\hline 0 & 6 & 0.0027 & 0.0023 & 0.0032 & 67 & 0.00020 & 0.5636 & 13.40 & 0.228 \\
\hline 0 & 7 & 0.0029 & 0.0025 & 0.0032 & 79 & 0.00017 & 0.5831 & 17.26 & 0.147 \\
\hline 0 & 8 & 0.0024 & 0.0020 & 0.0028 & 56 & 0.00019 & 0.6469 & 12.90 & 0.170 \\
\hline 0 & 9 & 0.0028 & 0.0024 & 0.0032 & 41 & 0.00020 & 0.6359 & 14.34 & 0.201 \\
\hline 0 & 10 & 0.0026 & 0.0021 & 0.0031 & 26 & 0.00025 & 0.7646 & 10.38 & 0.221 \\
\hline
\end{tabular}


Acknowledgements. We wish to thank Anders Ferno, Stein Kaartvedt and 3 anonymous referees for comments on the manuscript and Frank Midtoy for helpful technical assistance. Gunnar Nyhammer and Erling Otterlei are also thanked for providing the fish and for advice on how to avoid common pitfalls in experimental work on marine fish. This work was funded by the Research Council of Norway (Research grant no. $113726 / 122$ )

\section{LITERATURE CITED}

Bagge $O$ (1977) Meal size and digestion in cod (Gadus morhua L.) and sea scorpion (Myoxocephalus scorpius L.). Medd Dan Fisk Havunders 7:437-446

Bindoo M, Aravindan CM (1992) Influence of size and level of satiation on prey handling time in Channa striata (Bloch). J Fish Biol 40:497-502

Booth DJ (1990) Effect of water temperature on stomach evacuation rates, and estimation of daily food intake of bluegill sunfish (Lepomis macrochirus Rafinesque). Can J Zool 68 : $591-595$

Breck JE (1993) Foraging theory and piscivorous fish: are forage fish just big zooplankton? Trans of the Am Fish Soc 122:902-911

Brett JR, Higgs DA (1970) Effect of temperature on the rate of gastric digestion in fingerling sockeye salmon, Oncorhynchus nerka. J Fish Res Bd Can 27:1767-1779

Bromley PJ (1988) Gastric digestion and evacuation in whiting, Merlangius merlangus (L.). J Fish Biol 33:331-338

Bromley PJ (1991) Gastric evacuation in cod (Gadus morhua L. ). ICES Mar Sci Symp 193:93-98

Bromley PJ (1994) The role of gastric evacuation experiments in quantifying the feeding rates of predatory fish. Rev Fish Biol Fish 4:36-66

Bull CD, Metcalfe NB, Mangel M (1996) Seasonal matching of foraging to anticipated energy requirements in anorexic juvenile salmon. Proc R Soc Lond 263:13-18

Charnov EL (1976) Optimal foraging, the marginal value theorem. Theor Popul Biol 9:129-136

Cummins KW, Wuycheck JC (1971) Caloric equivalents for investigations in ecological energetics. Int Ver Theor Angew Limnol Verh 18:1-158

Daan N (1973) A quantitative analysis of the food intake of North Sea cod, Gadus morhua. Neth J Sea Res 6:479-517

Danulat E (1987) Digestibility of chitin in cod, Gadus morhua, in vivo. Helgol Meeresunters 41:425-436

Diana JS (1979) The feeding pattern and daily ration of a top carnivore, the northern pike (Esox lucius). Can J Zool 57: $2121-2127$

dos Santos J, Jobling $M$ (1988) Gastric emptying in cod, Gadus morhua L.: effects of food particle size and dietary energy content. J Fish Biol 33:511-516

dos Santos J, Jobling M (1991a) Gastric emptying in cod, Gadus morhua $\mathrm{L}$ : emptying and retention of indigestible solids. J Fish Biol 38:187-197

dos Santos J, Jobling M (1991b) Factors affecting gastric evacuation in cod, Gadus morhua L., fed single-meals of natural prey. J Fish Biol 38:697-713

dos Santos J, Jobling M (1992) A model to describe gastric evacuation in cod (Gadus morhua L.) fed natural prey. ICES J Mar Sci 49:145-154

Elashoff JD, Reedy TJ, Meyer JH (1982) Analysis of gastric emptying data. Gastroenterology 83:1306-1312

Elliott JM (1972) Rates of gastric evacuation in brown trout, Salmo trutta L. Freshw Biol 2:1-18

Ellis T, Gibson RN (1997) Predation of 0-group flatfishes by 0- group cod: handling times and size-selection. Mar Ecol Prog Ser 149:83-90

El-Shamy FM (1976) Analysis of gastric emptying in bluegill (Lepomis macrochirus). J Fish Res Board Can 33: $1630-1633$

Emlen JM (1966) The role of time and energy in food preference. Am Nat 100:611-617

Fänge R, Grove D (1979) Digestion. In: Hoar WS, Randall DJ, Brett JR (eds) Fish physiology. VIII. Bioenergetics and growth. Academic Press, New York, p 161-260

Flowerdew MW, Grove DJ (1979) Some observations of the effects of body weight, temperature, meal size and quality on gastric emptying time in the turbot, Scophthalmus maximus (L.) using radiography. J Fish Biol 14:229-238

Fosså JH (1991) The ecology of the two-spot goby (Cobiusculus flavescens Fabricius): the potential for cod enhancement. ICES Mar Sci Symp 192:147-155

Fretwell SD, Lucas HL (1970) On territorial behavior and other factors influencing habitat distribution in birds. Acta Biotheor 19:16-36

Fuiman LA, Batty RS (1994) Susceptibility of Atlantic herring and plaice larvae to predation by juvenile cod and herring at two constant temperatures. J Fish Biol 44:23-34

Giske J, Salvanes AGV (1995) Why pelagic planktivores should be unselective feeders. J Theor Biol 173:41-50

Godin JGJ (1981) Effect of hunger on the daily pattern of feeding rates in juvenile pink salmon, Oncorhynchus gorbuscha Walbaum. J Fish Biol 19:63-71

Godø OR, Gjøsæter J, Sunnană K, Dragesund O (1989) Spatial distribution of 0-group gadoids off mid-Norway. Rapp PV Réun Cons Perm Int Explor Mer 191:273-280

Grove DJ, Loizides LG, Nott J (1978) Satiation amount, frequency of feeding and gastric emptying rate in Salmo gairdneri. J Fish Biol 12:507-516

Grove DJ, Moctrezuma MA, Flett HRJ, Foott JS, Watson $T$, Flowerdew MW (1985) Gastric emptying and the return of appetite in juvenile turbot, Schopthalmus maximus L. J Fish Biol 26:339-354

Hart PJB, Gill AB (1992) Constraints on prey size selection by the three-spined stickleback: energy requirements and the capacity and fullness of the gut. J Fish Biol 40: 205-218

Hart PJB, Ison S (1991) The influence of prey size and abundance, and individual phenotype on prey choice by the three-spined stickleback, Gasterosteus aculeatus L. J Fish Biol 38:359-372

Hartleb CF, Moring JR (1995) An improved gastric lavage device for removing stomach contents from live fish. Fish Res 24:261-265

Holland B, Brown J, Buss DH (1993) Fish and fish products. The Royal Society of Chemistry, Cambridge

Hop H, Gjøsæter J, Danielssen DS (1992) Seasonal feeding ecology of cod (Gadus morhua L.) on the Norwegian Skagerak coast. ICES J Mar Sci 49:453-461

Hop H, Gjøsæter J, Danielssen DS (1994) Dietary composition of sympatric juvenile cod, Gadus morhua L., and juvenile whiting, Merlangius merlangus L., in a fjord of southern Norway. Aquacult Fish Manage 25:49-64

Hopkins A (1966) The pattern of gastric emptying: a new view of old results. J Physiol 182:144-149

Jobling M (1981a) Dietary digestibility and the influence of food components on gastric evacuation in plaice, Pleuronectes platessa L. J Fish Biol 19:29-36

Jobling $M$ (1981b) Mathematical models of gastric emptying and the estimation of daily rates of food consumption for fish. J Fish Biol 19:245-257

Jobling M (1982) Food and growth relationships of the cod, 
Gadus morhua L., with special reference to Balsfjorden. J Fish Biol 21:357-371

Jobling $M$ (1988) A review of the physiological and nutritional energetics of cod, Gadus morhua L., with particular reference to growth under farmed conditions. Aquaculture 70: $1-19$

Jobling M (1994) Fish bioenergetics. Chapman \& Hall, London

Jobling M, Davies PS (1979) Gastric evacuation in plaice, Pleuronectes platessa L.: effects of temperature and meal size. J Fish Biol 14:539-546

Jobling $M_{1}$ Hjelmeland $K$ (1992) Ernæering of fordøyelse. In: Doving $K$, Reimers E (eds) Fiskens fysiologi. John Grieg Forlag, Bergen, p 234-257

Jones $\mathrm{R}$ (1974) The rate of elimination of food from the stomachs of haddock Melanogrammus aeglefinus, cod Gadus morhua and whiting Merlangius merlangus. J Cons Int Explor Mer 35:225-243

Kapoor BG, Smith H, Verighina IA (1975) The alimentary canal and digestion in teleosts. Adv Mar Biol 13:109-239

Karpevich AF, Bokova EN (1937) Rates of digestion of marine fishes. Zool Zh 16:29-44 (Translation 1004, Department of Agriculture and Fisheries for Scotland)

Kennedy P (1992) A guide to econometrics, 3rd edn. Blackwell, Oxford

Kislalioglu M. Gibson RN (1976) Some Factors governing prey selection by the 15-spined stickleback, Spinachia spinachia (L.). J Exp Mar Biol Ecol 25:159-169

Knutsen I (1998) Application of a surface-dependent digestion model for estimating the digestion handling time in juvenile coastal cod Gadus morhua L. fed gobiids: meal size and temperature effects. Master's thesis, Dept of Fisheries and Marine Biology. University of Bergen

MacArthur RH, Pianka ER (1966) On optimal use of a patchy environment. Am Nat 100:603-609

Macdonald JS, Waiwood KG, Green RH (1982) Rates of digestion of different prey in Atlantic cod (Gadus morhua), ocean pout (Macrozoarces americanus), winter flounder (Pseudopleuronectes americanus), and American plaice (Hippoglossoides platessoides). Can J Fish Aquat Sci 39: $651-659$

Macpherson E, Lleonart J, Sanchez P (1989) Gastric emptying in Scyliorhinus canicula (L.): a comparison of surfacedependent and non-surface-dependent models. J Fish Biol $35: 37-48$

Mangel M, Clark CW (1986) Towards a unifying foraging theory. Ecology 67:1127-1138

Mangel M, Clark CW (1988) Dynamic modeling in behavioral ecology. Princeton University Press, Princeton

Moyle PB, Cech JJ (1988) Fishes. An introduction to ichthyology, 2nd edn. Prentice-Hall, Englewood Cliffs, NJ

Norris JS, Norris DO, Windell JT (1973) Effect of simulated meal size on gastric acid and pepsin secretory rates in bluegill (Lepomis macrochirus). J Fish Res Board Can 30: 201-204

Olson RJ, Mullen AJ (1986) Recent developments for making gastric evacuation and daily ration determinations. In: Simenstad CA, Cailliet GM (eds) Contemporary studies on fish feeding: the proceedings of GUTSHOP '84. Dr W' Junk Publishers, Boston, p 183-191

Persson L (1979) The effects of temperature and different food organisms on the rate of gastric evacuation in perch (Perca fluviatilis). Freshw Biol 9:99-104

Persson L (1986) Patterns of food evacuation in fishes: a critical review. In: Simenstad CA, Cailliet GM (eds) Contemporary studies on fish feeding: the proceedings of GUTSHOP '84. Dr W Junk Publishers, Boston, p 51-58
Pyke GH (1979) Optimal foraging in fish. In: Simenstad CA Cailliet GM (eds) Contemporary studies on fish feeding: the proceedings of GUTSHOP ' 84 . Dr W Junk Publishers, Boston, p 199-202

Pyke GH (1984) Optimal foraging theory: a critical review. Annu Rev Ecol Syst 15:523-575

Quigley JP, Meschan I (1941) Inhibition of the pyloric sphincter region by the digestion products of fat. Am J Physiol $134: 803-807$

Rodrigues AMP (1994) Digestibility studies in fish: a review. Monografias 6, Instituto de Zoologia, Universidade do Porto

Salvanes AGV (1994) Fødevalsmekanismar for fisk og mekanistisk modellering av fødeval i fleirbestandsmodellar. IFM-report No. 14/1994. Department of Fisheries and Marine Biologry, University of Bergen (English summary)

Salvanes AGV, Hart PJB (1998) Individual variability in state. dependent feeding behaviour in three-spined sticklebacks. Anim Behav 55:1349-1359

Salvanes AGV, Noreide JT (1993) Dominating sublittoral fish species in a west Norwegian fjord and their trophic links to cod (Gadus morhua L.). Sarsia 78:221-234

Salvanes AGV, Aksnes DL, Giske J (1995) A surface-dependent gastric evacuation model for fish. J Fish Biol 47: $679-695$

Schurmann $H_{1}$ Steffensen JF (1997) Effects of temperature, hypoxia and activity on the metabolism of juvenile Atlantic cod. J Fish Biol 50:1166-1180

Seaburg KG, Moyle JB (1964) Feeding habits, digestive rates, and growth of some Minnesota warmwater fishes. Trans Am Fish Soc 93:269-285

Shoener TW (1987) A brief history of optimal foraging theory. In: Kamil JR, Krebs JR, Pulliam HR (eds) Foraging behaviour. Plenum Press, New York, p 5-67

Singh-Renton S, Bromley PJ (1996) Effects of temperature, prey type and prey size on gastric evacuation in small cod and whiting. J Fish Biol 49:702-713

Sitaramaiah P (1967) Water, nitrogen and caloric values of freshwater organisms. I Cons Perm Int Explor Mer 31: $27-30$

Smit H (1967) Influence of temperature on the rate of gastric juice secretion in the brown bullhead, Ictalurus nebulosus. Comp Biochem Physiol 21:125-132

StatSoft $^{\oplus}$ (1994) Statistica for Windows (Vol III): Statistics II Statsoft. Tulsa

Steingrund P (1993) Forskjeller i beiteatferd mellom oppdrettet og vill torsk (Gadus morhua L.) og effekt av laering: to ulike beitestrategier på tangkutling (Gobiusculus flavescens Fabricius). Cand Scient thesis, University of Bergen

Steingrund P, Fernö A. (1997) Feeding behaviour of reared and wild cod and the effect of learning: two strategies of feeding on the 2-spotted goby. J Fish Biol 51:334-348

Stephens DW, Krebs JR (1986) Foraging theory. Princeton University Press, Princeton

Street NE, Magurran AE, Pitcher TJ (1984) The effects of increasing shoal size on handling time in goldfish, Carassius auratus $\mathrm{L}$. J Fish Biol 25:561-566

Svåsand T, Kristiansen TS (1990) Enhancement studies of coastal cod in western Norway. Part II. Migration of reared coastal cod. J Cons Int Explor Mer 47:13-22

Swenson WA, Smith LL Jr (1973) Gastric digestion, food consumption, feeding periodicity, and food conversion efficiency in walleye (Stizostedion vitreum vitreum). J Fish Res Board Can 30:1327-1336

Tarverdieva MI (1962) Some data on the feeding of the Barents Sea cod Gadus morhua morhua L. in experimental 
conditions. Voprosy Ikhtiologii 2:703-716 (Translation by McLean C 1964, Ministry of Agriculture, Fisheries and Food 4)

Tseitlin VB (1980) Duration of gastric digestion in fishes. Mar Ecol Prog Ser 2:277-280

Tyler AV (1970) Rates of gastric emptying in young cod. J Fish Res Board Can 27:1177-1189

Tyler AV (1973) Alimentary tract morphology of selected North Atlantic fishes in relation to food habits. Fish Res Board Can Tech Rep 361

Tyler AV (1977) Evidence for the assumption of independence

Editorial responsibility: Roger Hughes (Contributing Editor), Bangor, Gwynedd, Wales, UK between gastric emptying rate and swiming activity using Atlantic cod, Gadus morhua. J Fish Res Board Can 34 : 2411-2413

Werner EE (1974) The fish size, prey size, handling time relation in several sunfishes and some implications. J Fish Res Board Can 31:1531-1536

Windell JT (1966) Rate of digestion in the bluegill sunfish. Invest Indiana Lakes Streams 7:187-214

Windell JT (1978) Digestion and the daily ration of fishes. In: Gerking SD (ed) Ecology of freshwater fish production. Blackwell, Oxford, p 159-183

Submitted: August 14, 1998; Accepted: December 16, 1998 Proofs received from author(s): April 26, 1999 